\title{
НУМІЗМАТИЧНІ СТУДІЇ
}

\author{
R. O. Kozlenko, I. M. Sheiko, A. Reuter
}

\section{COINS FROM EXCAVATIONS AT THE «T-4» SECTOR IN OLBIA}

Coins are published from the latest excavations at "T-4" sector, laid in 2018 in the Terrace City of Olbia. The presented numismatic material covers all the main chronological periods of the polis existence.

Keywords: Olbia, sector "T-4», coins, dolphin-shaped coins, borysthenes coins, Byzantium, Amis, Istria.

In 2018, in the Terrace City of Olbia, in order to resume the search for the theater, a new excavation site «T-4» was laid (fig. 1). Director from the Ukrainian side - D. Sc. in History A. V. Buiskykh, from the German - prof. J. Fornasier. Head of the excavation sector - Ph. D in History I. M. Sheiko. Its presence is assumed due to the decrees of the Hellenistic time in honor of Callinicos (IOSPE I $\left.{ }^{2} 25\right)$, Anthesterion (Vinogradov 1984, p. 75), and the sons of Apollonius (HO 28), which contain the mention of the Olbian $\theta \dot{\varepsilon} \alpha$ cov.

The search for the theater was carried out by A. N. Karasev in the late 1950s (prospecting trench to the east of excavation «E», Western Trade Row), and under the head of S. D. Kryzhytskyi in the late 1980s and early 1990s (excavations «T», «T-1», «T-2», «T-3»). These works can be united due to a small area of research and their location in different places of the Terrace City, the natural micro-relief of which suggests the construction of a theatron.

The results of the research at excavations «T» and «T-1» (headed by V. V. Nazarov) were the discovery of the redeposited massifs of soil displaced from the territory of the Upper City and the slope (as a result of a landslide?), mixed with a subsoil clay. At excavation "T-2» (headed by V. I. Nazarchuk), a room of the II-III c. AD was partially discovered, most likely, of economic purposes. At excavation «T-3» (headed by V. I. Nazarchuk), a rich dwelling with a courtyard and a cistern, located along the perimeter premises, including an andron, with basements, as well as a street with a retaining wall of the terrace, were discovered. Under the floor of one of the basements, a part of a residential building of the end of the VI c. BC was revealed.

In 2017, within the framework of an international Ukrainian-German project, a method of geophysical research was successfully tested ${ }^{1}$, which made it possible to identify a new defensive system that enclosed the suburban area from the field, and numerous residential, religious and economic structures of the suburb, as well as to prove their presence by archaeological means.

Moreover, the entire cup of the Terrace City was explored from the north to the south using ground-penetrating radar IDS DETECTOR DUO with dual frequency $250-700 \mathrm{MHz}$ antenna (IDS Georadar s. r. l.). The exploration was carried out in fifteen bands, 40-60 m long, each of which showed the presence of abnormalities. Conventionally, these exploration bands were combined into three blocks: F1, F2, and F3. The main number of abnormalities had clear rectangular elongated outlines, which, when decrypted, were attributed as walls, mainly retaining walls of terraces.

Of greatest interest are the results obtained at the bands of the F2 block, where abnormalities at the depth of $2.7-3.6 \mathrm{~m}$ have distinct curvatures with a bend to the west, which presumably resembles the contours of a theatron, which con-

1. This research was carried out by Dr. A. Patzelt. We would like to express our grateful thanks to the Fritz Thyssen Stiftung für Wissenschaftsförderung, which financed the research. 


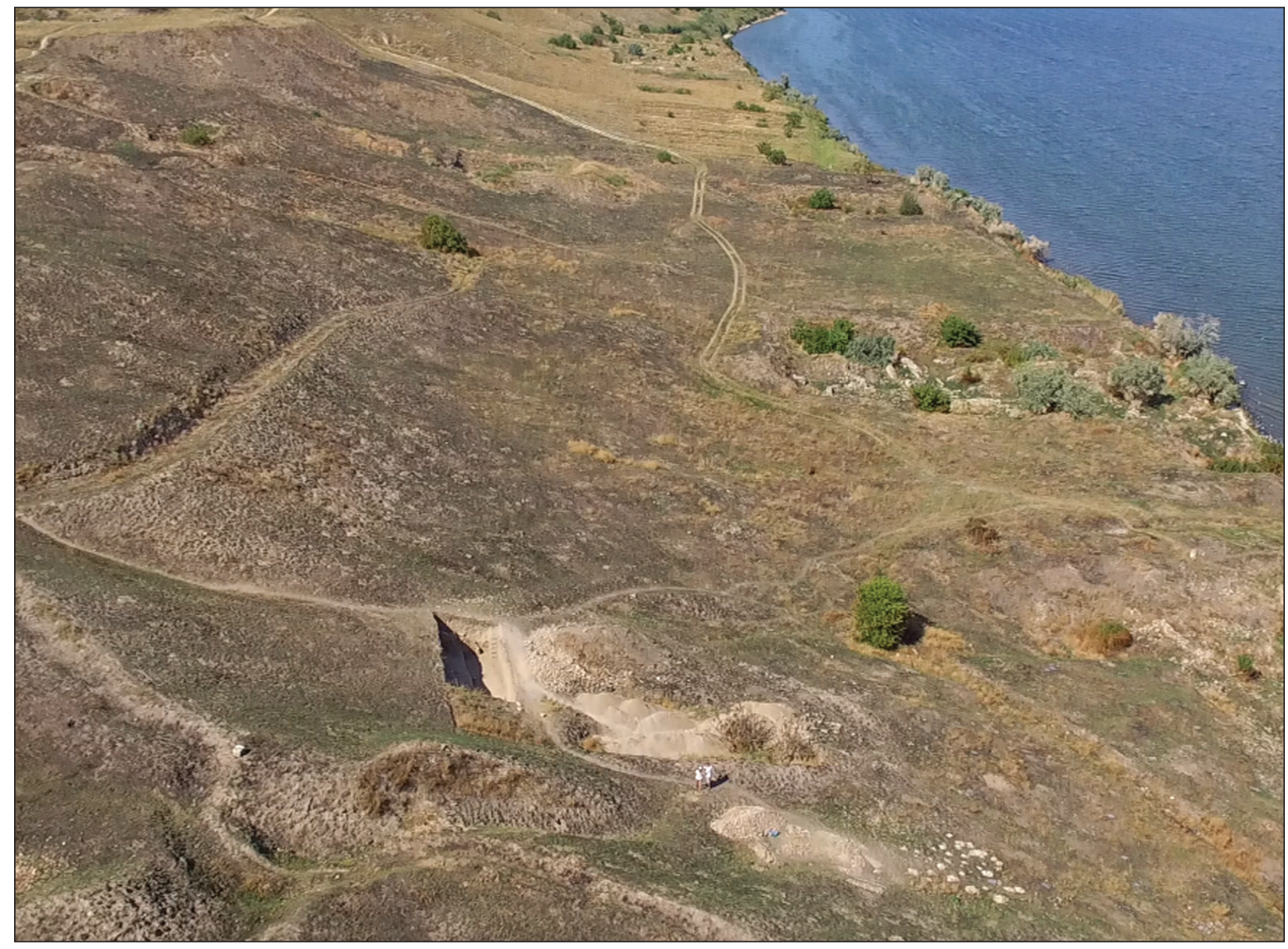

Fig. 1. The «T-4» site in the terraced part of Olbia. View from the south

sisted of sectors with the seats of the ancient theatre. In this place, to check these anomalies, it was decided to lay a search excavation, named according to the tradition, like all similar excavation attempts to find the theatre in the Terrace City, «T-4».

Due to the terraced location of the site, the archaeological material found in the cultural strata of the slope is often mixed. The excavation area is currently $60 \mathrm{~m}^{2}$. The depth from the level of the modern day surface from the western side is $4.5 \mathrm{~m}$. The stratigraphy of the «T-4» site includes five strata: the upper humus layer, the yellowashy layer, the gray-ashy layer, and the gray-ashy layer with yellow-clay inclusions (fig. 2). The depth of the layers has significant differences towards the southern part of the excavation.

Excavations at the «T-4» sector over three seasons of research have provided abundant numismatic material, which is published in this article. The total number of coins found is 154 . Among them, 34 coins cannot be precisely defined due to poor preservation. The Appendix includes the most decent coins in the amount of 91 items. Half of the found coins are casted dolphin-shaped coins 77 items.

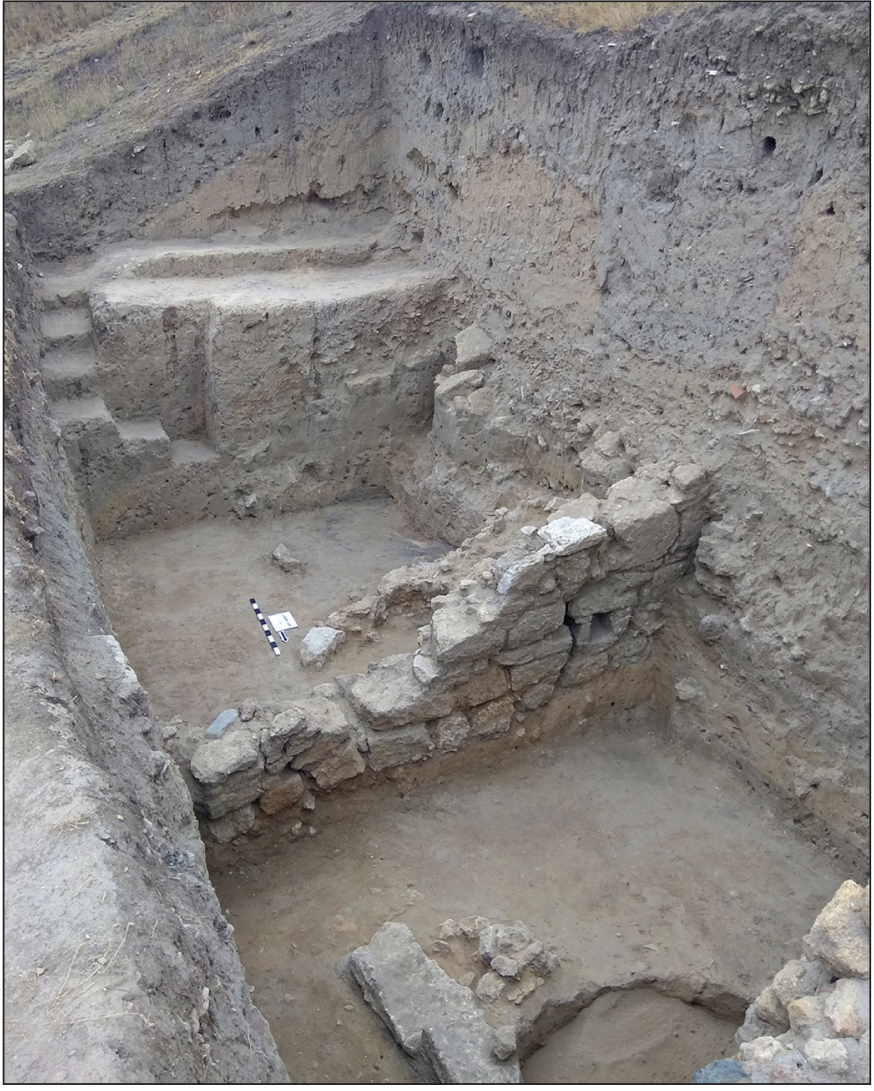

Fig. 2. The «T-4» sector in 2020. View from the north-east 


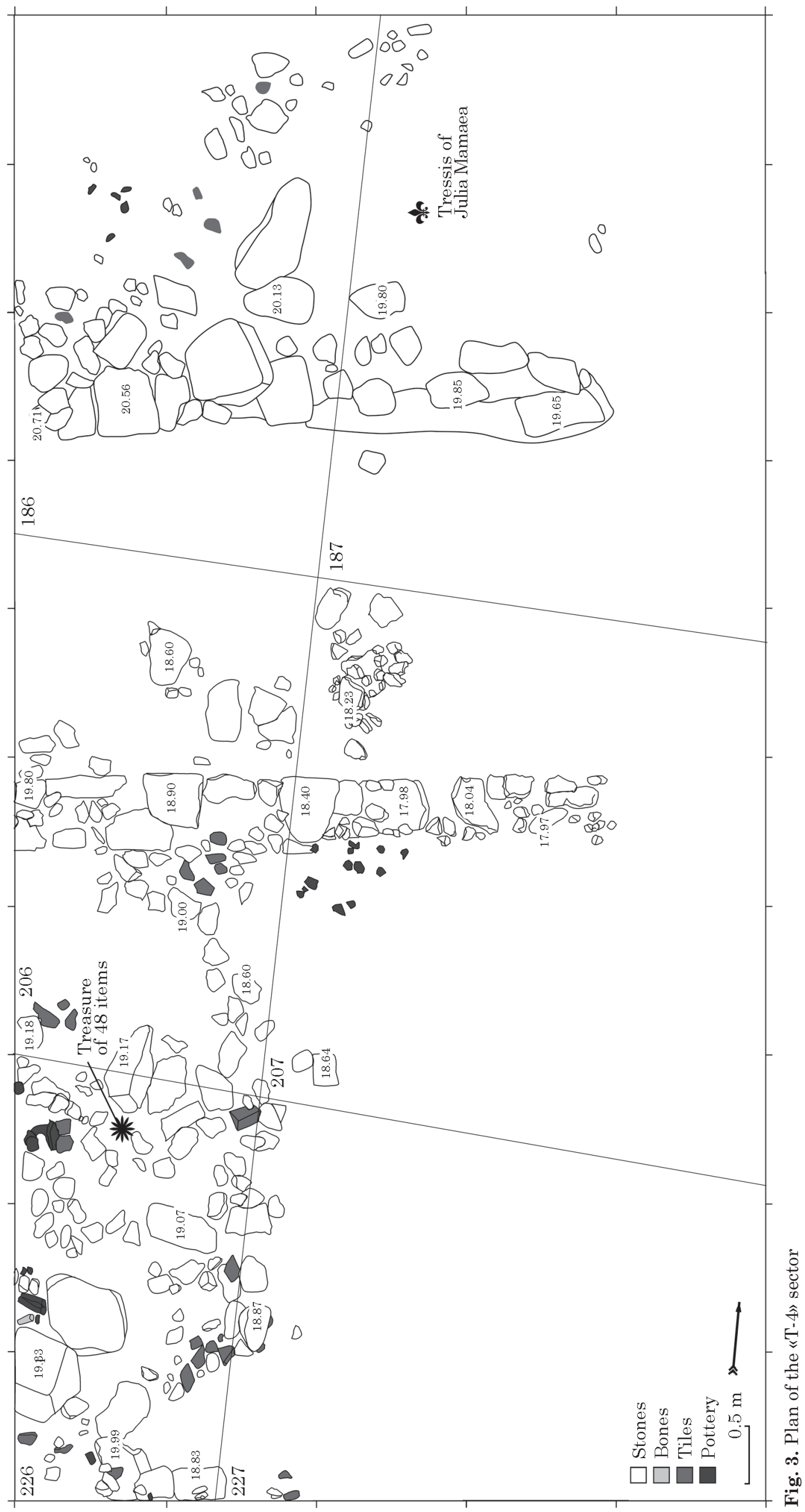


Archaic and Classical periods. Researchers are unison in opinions about the appearance of dolphin-shaped coins - from the second half of the VI c. ВC (Зографр 1951, с. 121-124; Харко 1964 , с. $321-323$; Карышковский 1988 , с. $34-$ 35; Анохин 1989, с. 8-9), however, views on the duration of their usage as monetary items vary from the V c. BC (Карышковский 1988, с. 37; Золотарьов 1997, с. 143) until the middle of the IV c. BC (Зографр 1951, с. 124; Харко 1964, c. 323), and until the end of this century (Анохин 1989, c. 10).

In order to clarify their dating, casted dolphin-shaped coins were repeatedly undergone classifications (Зографр 1951, с. 121-124; Харко 1964, c. 323-330; Chistov 2019, p. 99-107), in which stylistic features of coins and their weight became the determinative ones. Other points of view state that the proposed classifications are artificial, and the stratigraphic method remains the main one in their dating (Золотарьов 1997, c. $142-143)$.

In 2018-2019 at the western side of the excavation sector «T-4» (fig. 3), in quadrat No. 226 , in a gray-ashy layer overlapped by a yellow clay adobe massif, among small and medium limestone quarries and collapses of pottery, an accumulation of bronze finds was revealed: dolphin-shaped coins in the amount of 26 items (fig. 3: 8-10, 17-26; 4: 27, 39-42), fragments of fibulae, and five arrowheads. A total of 48 items were recorded.

The period of wide distribution of dolphinshaped coins falls on the $\mathrm{V} \mathrm{c}$. BC, which finds confirmation in the form of dating the material found along with this accumulation of coins, namely: Protothasos, Thasos, Chios, Lesbos and Knid amphorae, black-glazed Attic dishes, as well as bronze three-bladed arrowheads that are dated by the $\mathrm{V}-\mathrm{IV}$ c. BC.

It should be noted that fragments of mosaic floors made of multi-colored pebbles found in the filling of this building at the level of the bottom of its northern masonry make it possible to consider the investigated part of this room, in which a hoard of dolphin-shaped coins was found, as a separate closed complex in this area.

The representative sample contains several main types of dolphin-shaped coins (fig. 6), which confirm the point of view of their synchronous existence. The absence of casted arrow-shaped coins in this hoard confirms the diachronic feature of these emission groups (for more details see: Рубан 1982, c. 15-20; Chistov 2019, p. 101). Epigraphic dolphin-shaped coins with the inscription $\Theta Y$ (fig. 5: 31, 42), one of which comes from the hoard, belong to the third group of these coins (Харко 1964, с. 326-329), and is dated by the V c. ВC (Зограбр 1951, с. 121-124; Харко 1964, с. 326-329; Карышковский 1988, с. 35).

The coins found in Olbia with the image of a wheel on the obverse and the inscription I $\Sigma T$ on the reverse originate from Istria (Карышковский
1960, c. 138-140), and are dated by the V-IV c. ВC (Загинайло 1991, с. 57-59; Секерская, Булатович 2010 , с. 28). The "wheel» from the excavations of the «T-4» sector (fig. 7: 49), judging by its size, belongs to the second subgroup of these coins according to A. H. Zahynailo (Загинайло 1991, c. 58).

The classical period in Olbia is completed by early issues of coins depicting Demeter and an eagle on a dolphin (fig. 7: 50-59), as well as Tyche in a tower crown, and a kneeling archer (fig. 7: 60—61), which are dated by 380-350 BC (Анохин 1989, с. 31-32; Карышковский 2003, c. $179-180)^{1}$

The coin of the city of Byzantium found at the «T-4» site is dated by the same time. Its obverse depicts the front part of a bull on a dolphin, and on the reverse - a tripod between two dolphins (fig. 7: 62). It is dated by $387-340 \mathrm{BC}^{2}$. (SNG IX: 14-20). About the trade relations between Olbia and Byzantium in the IV c. BC is evidenced by the Olbian inscription in honor of the Byzantine citizen Deloptych, the son of Meniscus, to whom the Olbian citizens granted a proxeny, the right of citizenship, and exemption from duties on all goods (HO 9). The Byzantium coin, located on the European coast of the Bosphorus, can be attributed to a rare numismatic find in Olbia, which confirms the existence of economic contacts between these cities.

Hellenistic period. From the second half of the IV c. BC casted coins in Olbia are supplanted by minted ones. Coins of the Hellenistic period from the excavations at the «T-4» sector are presented by small denominations with the image of Demeter or Apollo, and the city emblem - an eagle on a dolphin (fig. 7: 63-72; 8: 82), Apollo with a kneeling archer (fig. 8: 78-79), and Olbian coins - borysthenes (fig. 8: 73-77). Some coins with the image of Apollo have sprues (fig. 7: 64 ), which testify to the collective production of coins ${ }^{3}$.

In addition to the dolphin-shaped coins, which appear in Olbia and its associated territory in unbelievably high quantities, there is another genus of Olbian monetary objects, which already attract attention through their sheer quantity. These are strikingly small, low-weight coins made of copper or copper alloy, which often weigh less than one gram and reach a length diameter of approx. $0.8 \mathrm{~cm}$. It is important to differentiate between

1. Another point of view about Demeter / archer coins, dated by the last third of the IV c. BC - the time of the Zopirion campaign in Olbia, see: Снытко, Туровский 2000, с. 400-401; Stolba 2015, p. 4950.

2. Found among ceramic materials of the V-III c. BC (Буйских и др. 2020, с. 16), together with coins of the IV c. BC (fig. 7: 55).

3. On the casting technique, the casting of circles and the minting of Olbian coins, see: Карышковский 1999, c. 27-29. 


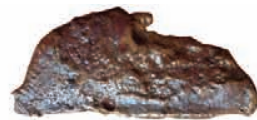
1
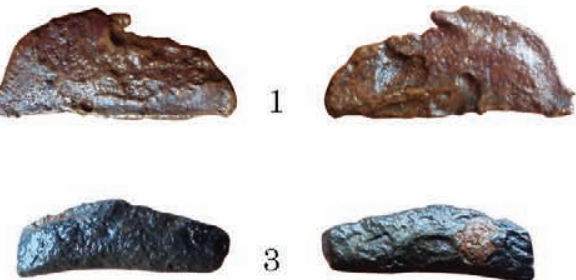
3
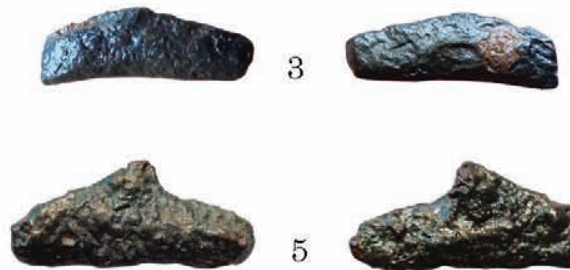

5
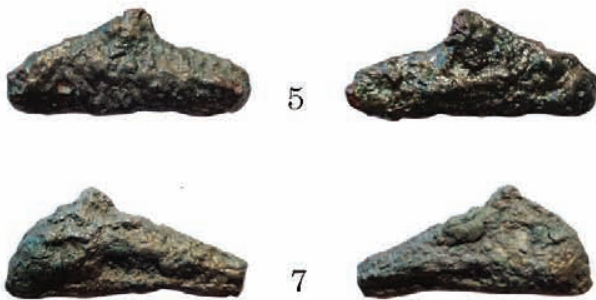

7
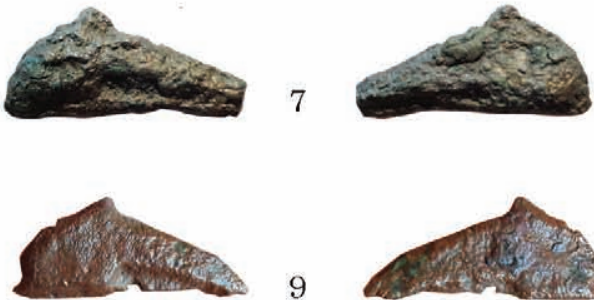

9
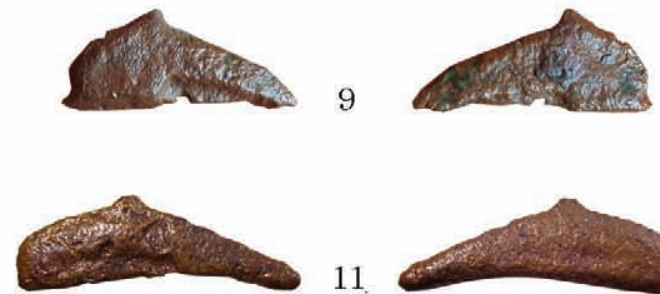

11
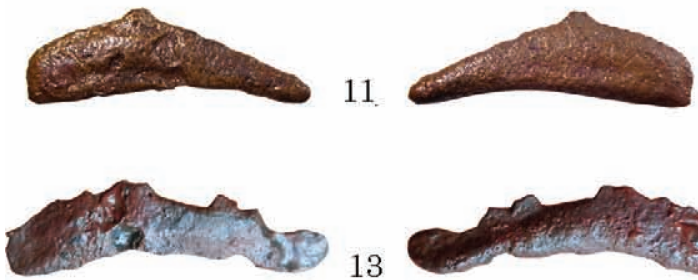

13
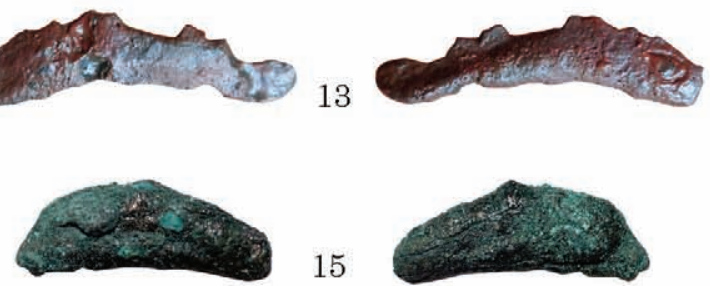

15
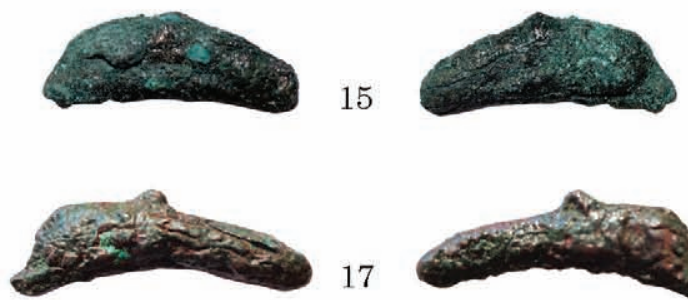

17
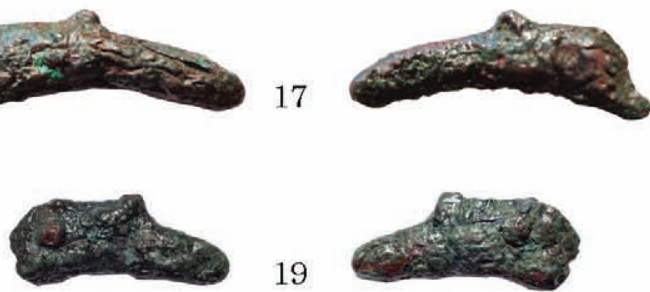

19
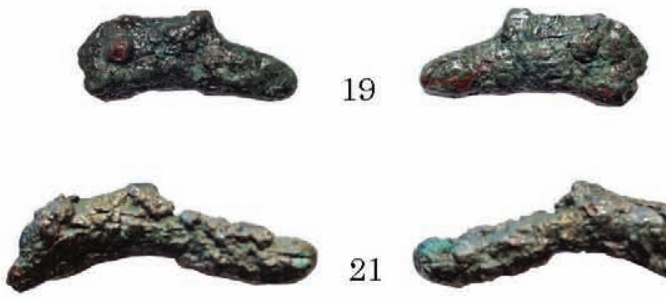

21
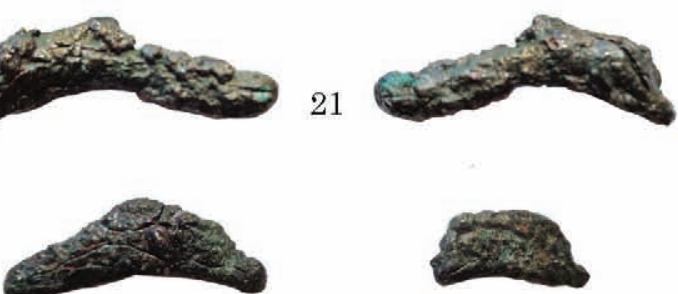

23

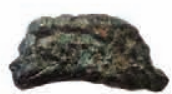

24
Group 2
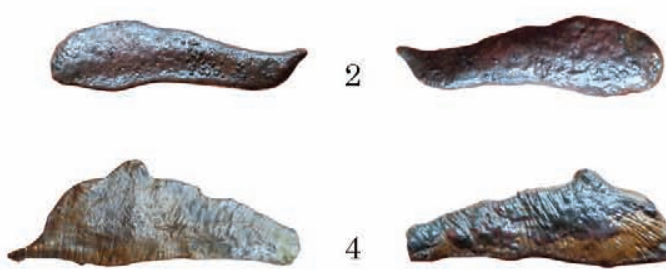

4
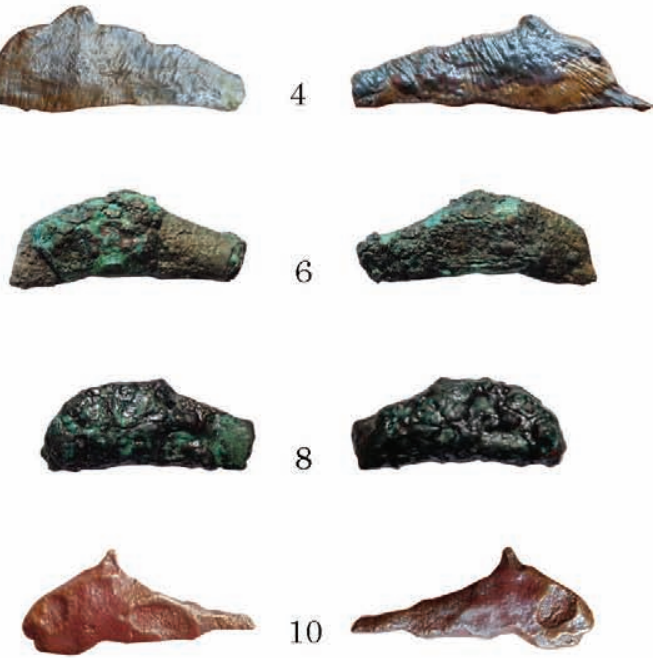

10

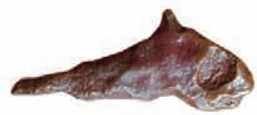

Group 3

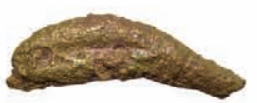

12
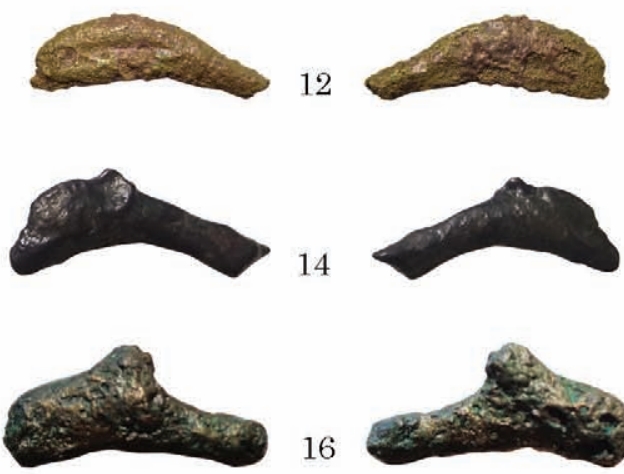

16
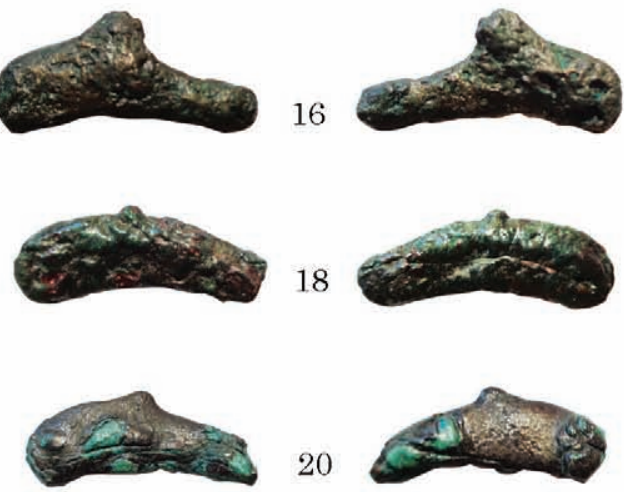

20
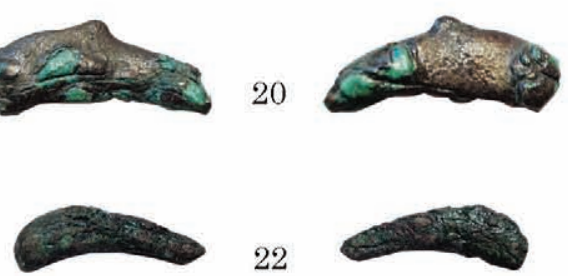

22

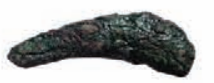

$1 \mathrm{~cm}$
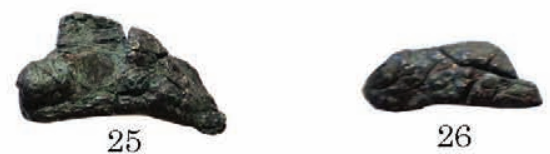

Fig. 4. Casted dolphin-shaped coins from the excavation site «T-4» in Olbia

two minting phases, which can be clearly separated both chronologically and in terms of the images used. While the early series are dated by the first half of the IV c. BC and show Demeter in profile on the front side and a dolphin and an ear of corn on the reverse (Anokhin 2011, p. 44-45, fig. 215-218; Reuter 2021, s. 6), the later miniature coins are dated between 330 and $320 \mathrm{BC}$ and show Apollo in profile on the obverse, while the dolphin on the reverse is accompanied either by a bow and arrow or a single grain, depending on the interpretation (Anokhin 2011, p. 58-59, 

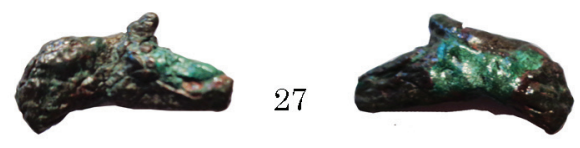

Group 3

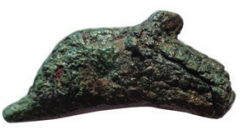

29
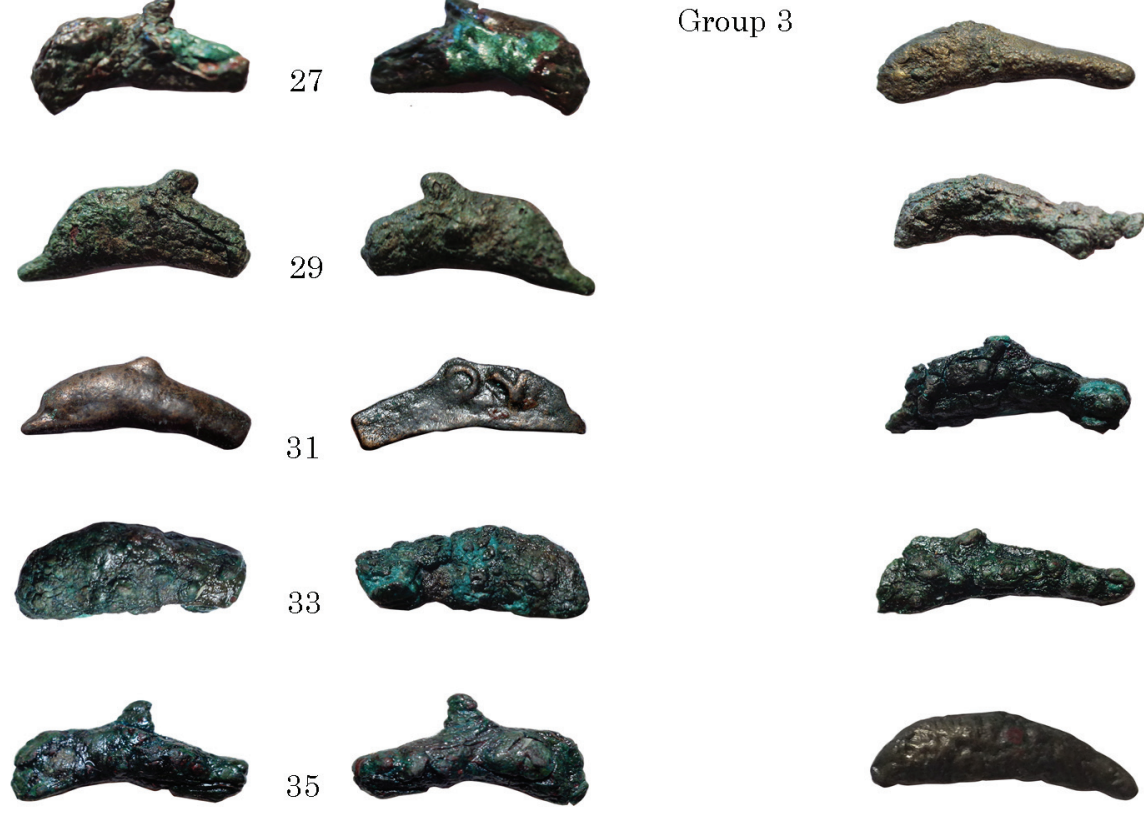

28
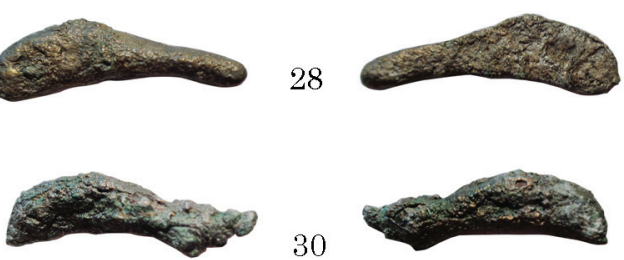

30
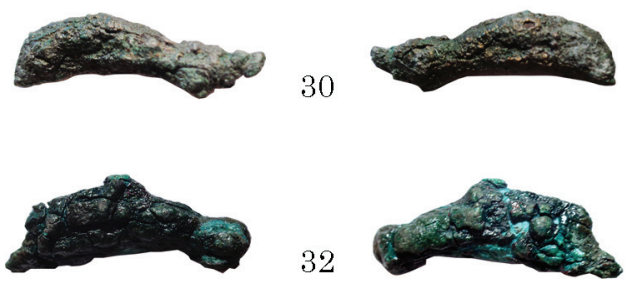

32
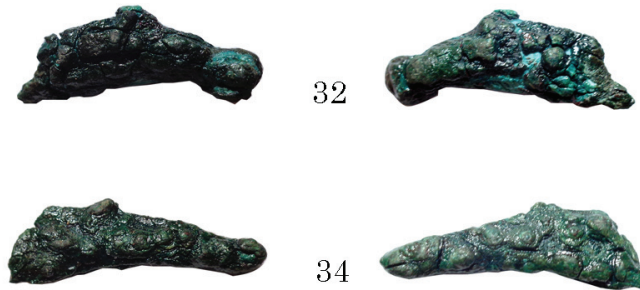

34
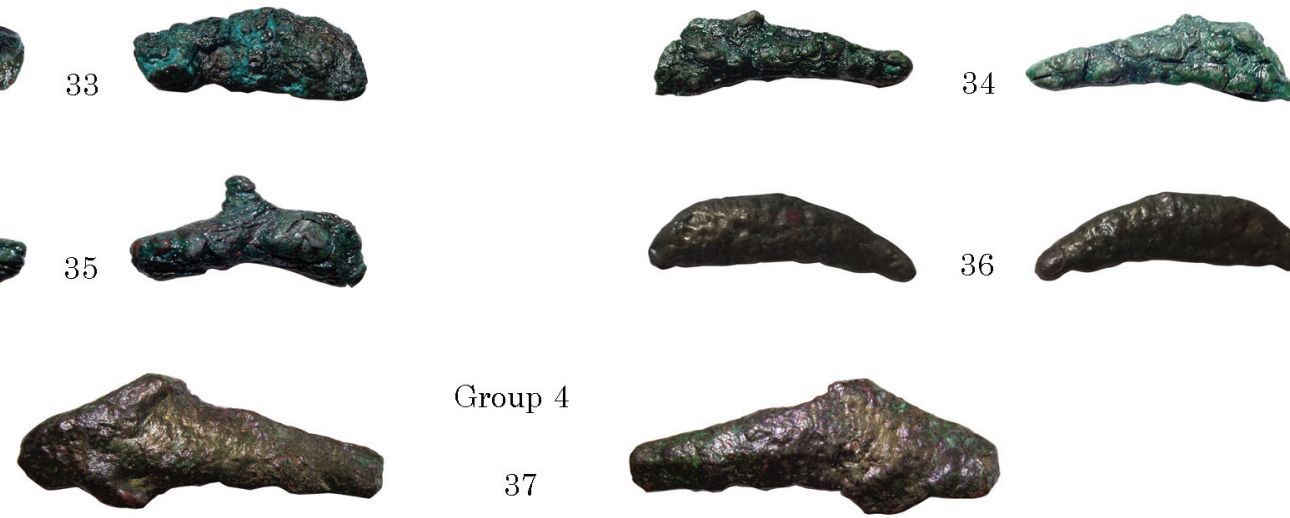

Group 4

37
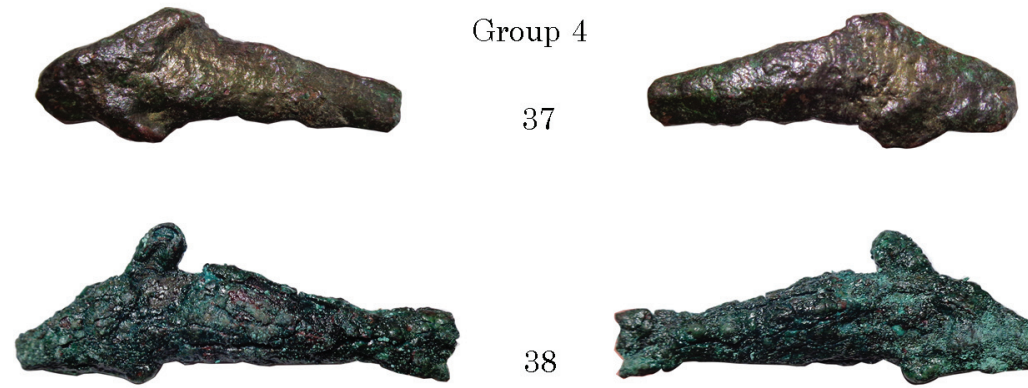

38
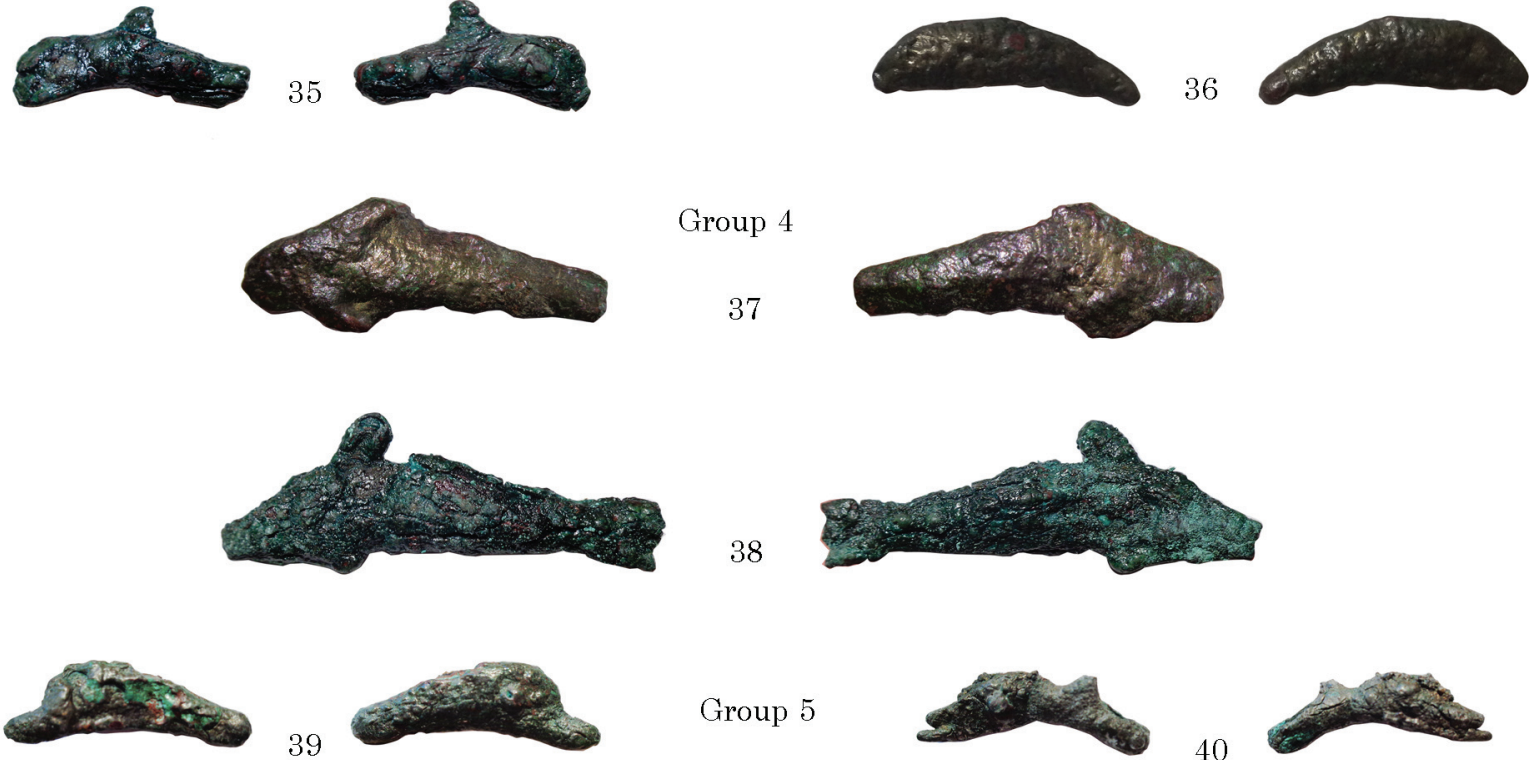

39

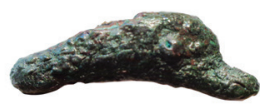

Group 5
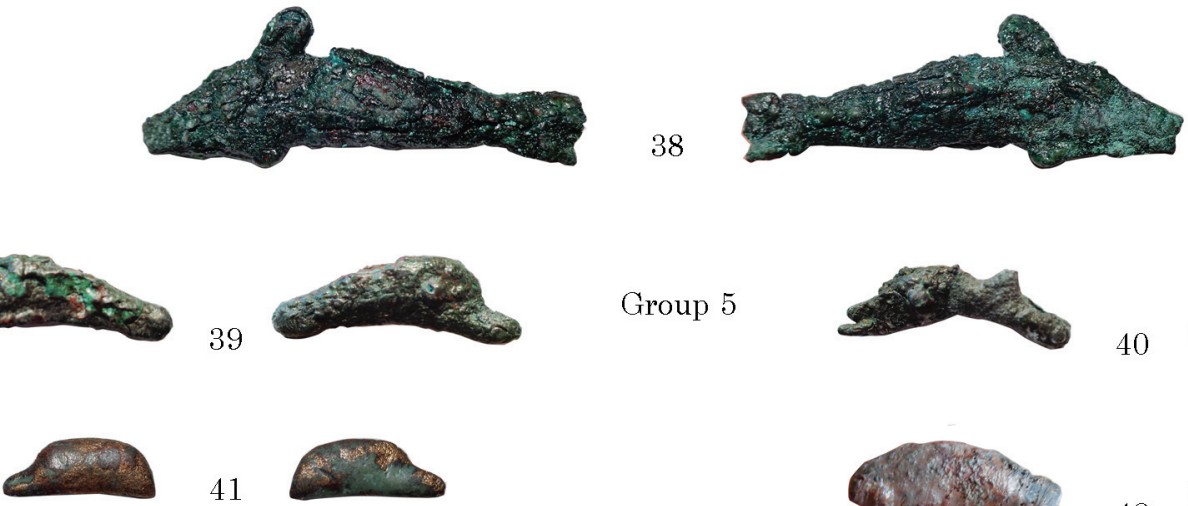

41
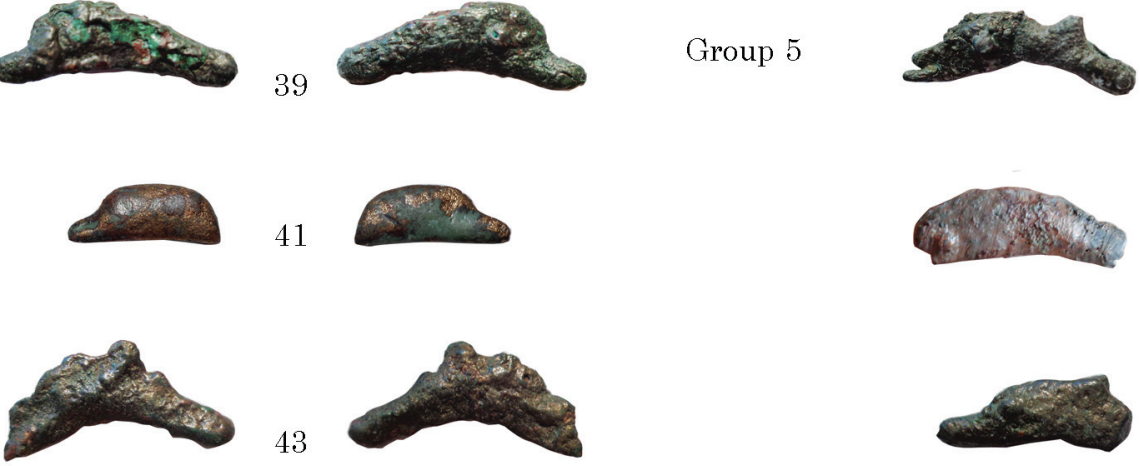

40
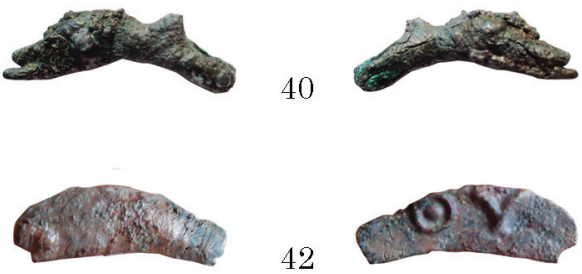

42
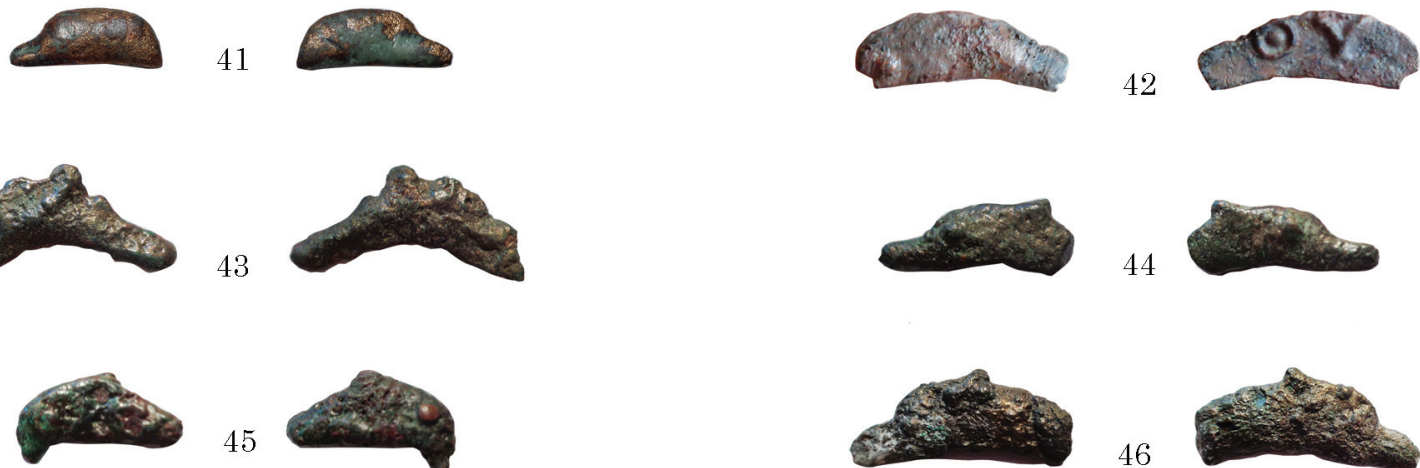

45
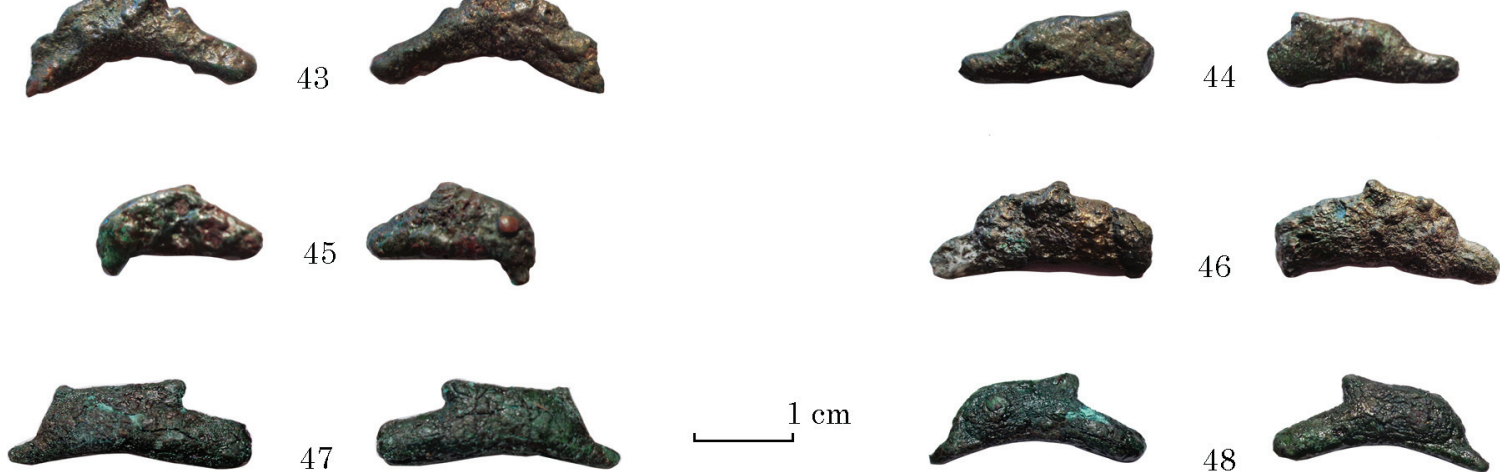

47
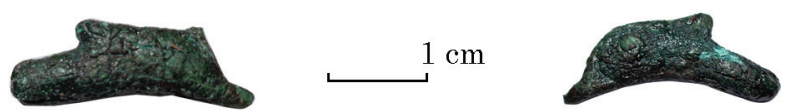

48

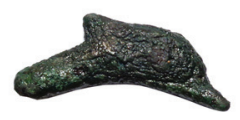

Fig. 5. Casted dolphin-shaped coins from the excavation site «T-4» in Olbia

fig. 284). Common to both embossing phases, however, is the inscription of the Olbian settlement on the lapel.
Together with their larger counterparts, which also show the goddess of agriculture on the obverse, while the reverse shows the symbol of an 


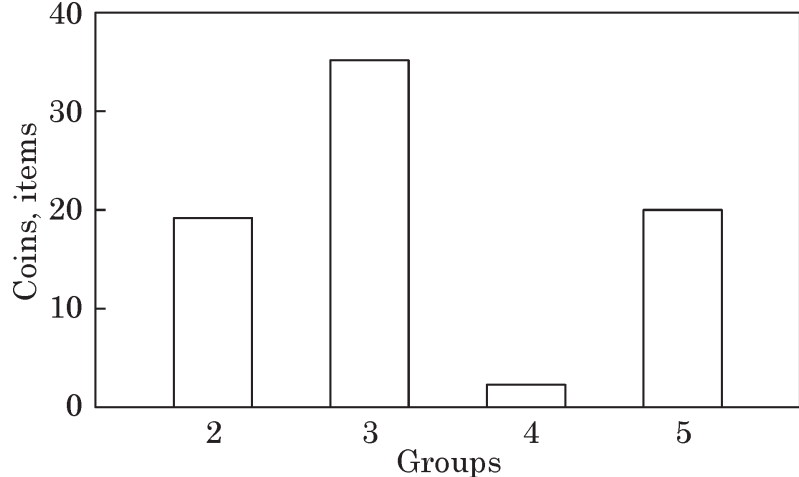

Fig. 6. Diagram of the groups distribution of dolphinshaped coins from the excavation site «T-4» eagle with a dolphin in its claws, a picture which is significant for Olbia, the early small coins with Demeter as well as the ear of corn and dolphin, initiate a change within the Olbian monetary system (Reuter 2021, s. 12). While all objects of Olbian origin with monetary function had previously been created by casting, which included both the so-called dolphin-shaped or fish-shaped money and the large and small asses (Anokhin 2011, p. 30-43), their successors of the IV c. BC are continuously minted. The only exception to this is the series of large asses with a goddess en face, probably Demeter on the obverse and an eagle with a dolphin on the reverse, which, after a long

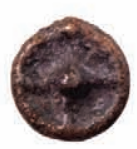

49
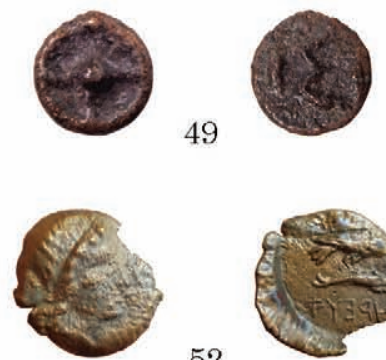

52
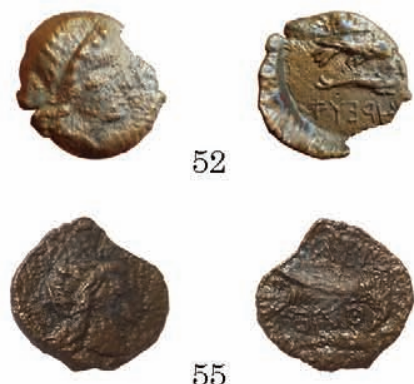

55
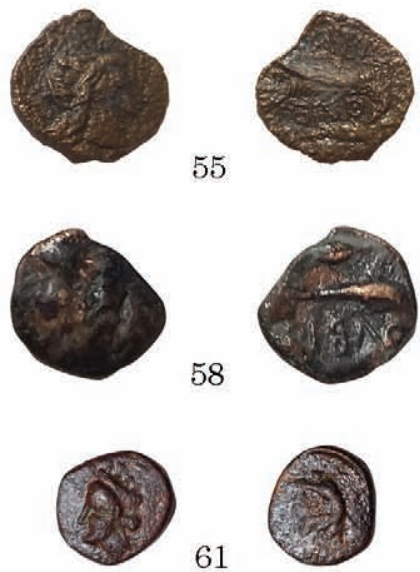

61
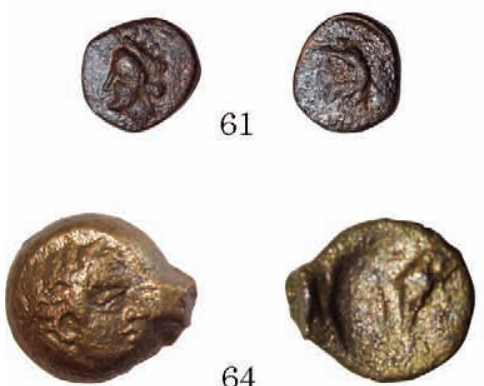

64

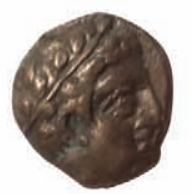

67
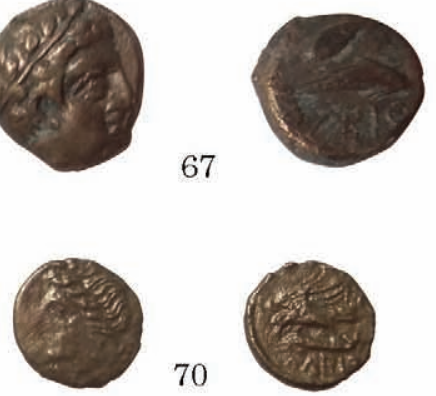

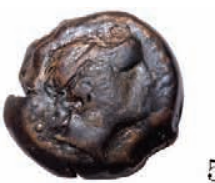

50
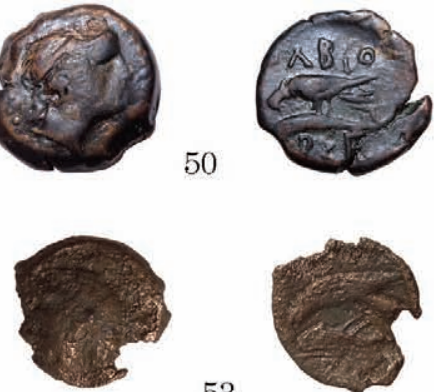

53
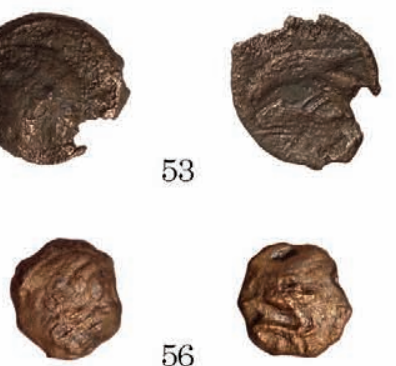

56
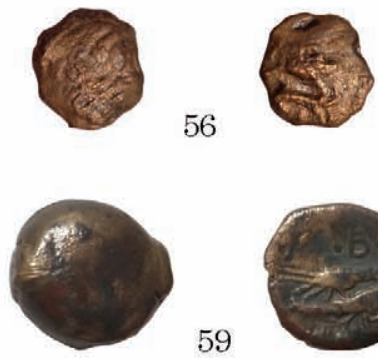

59
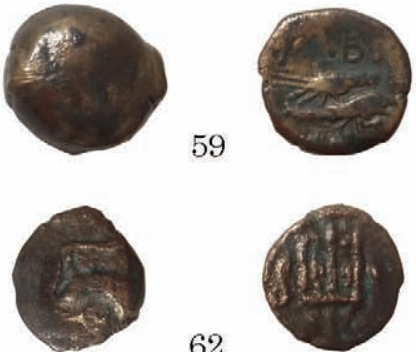

62
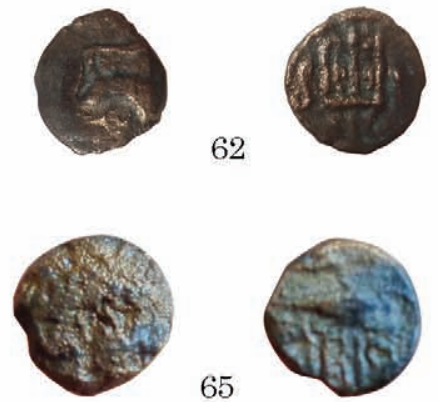

65
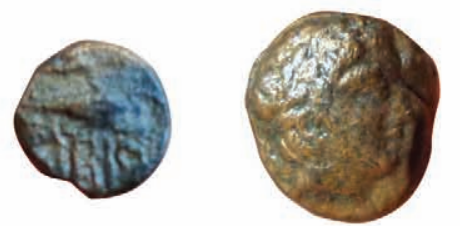

66

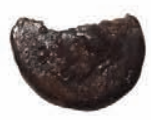

68
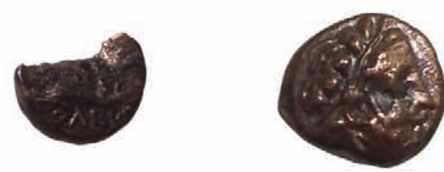

69

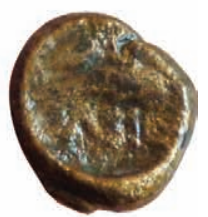

71
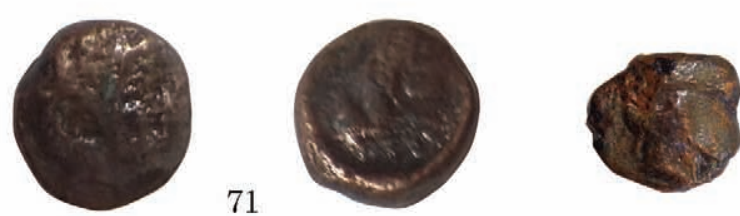

72

$0.5 \mathrm{~cm}$

Fig. 7. Olbian coins of the Classical and Hellenistic periods from the excavation site «T-4» in Olbia 


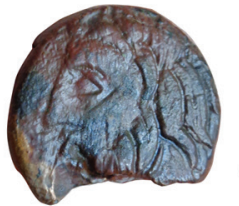

73
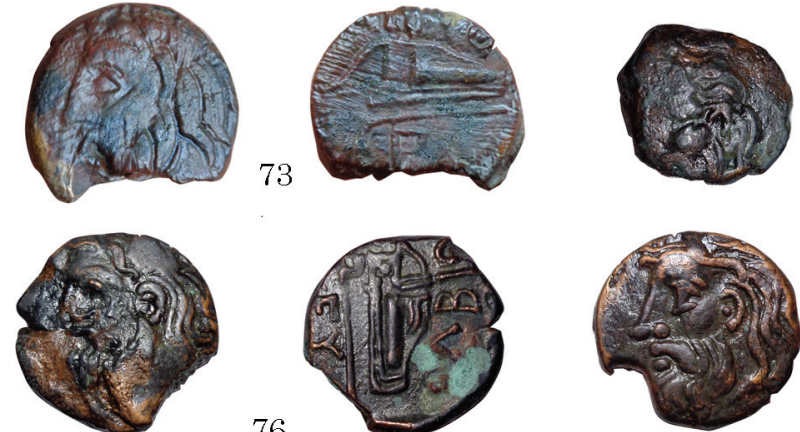

76
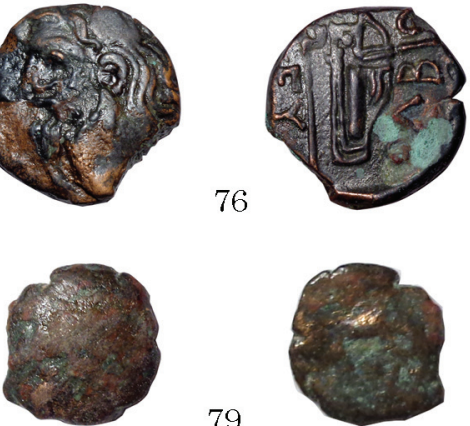

79
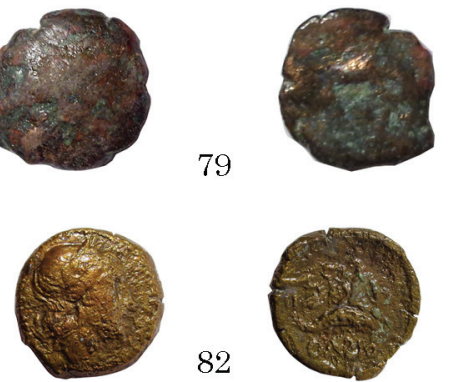

82
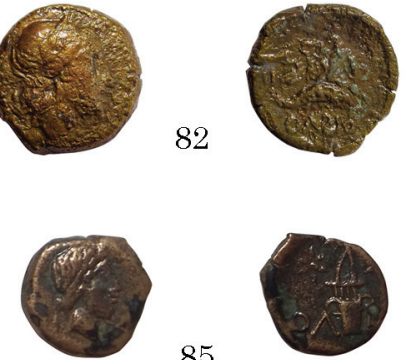

85
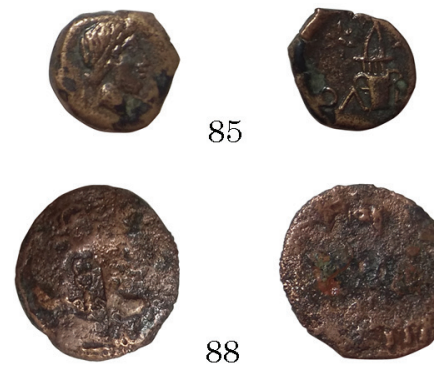

88
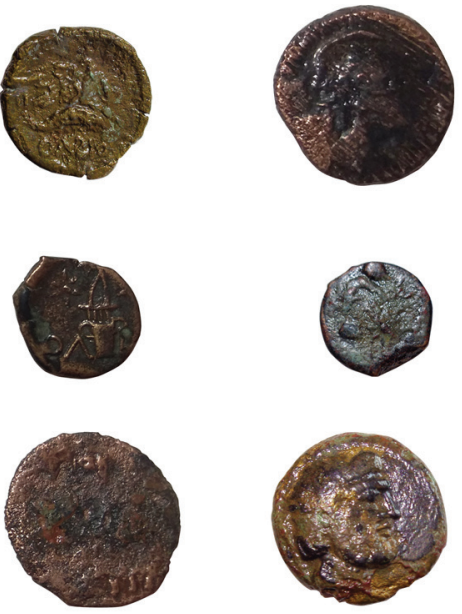

83
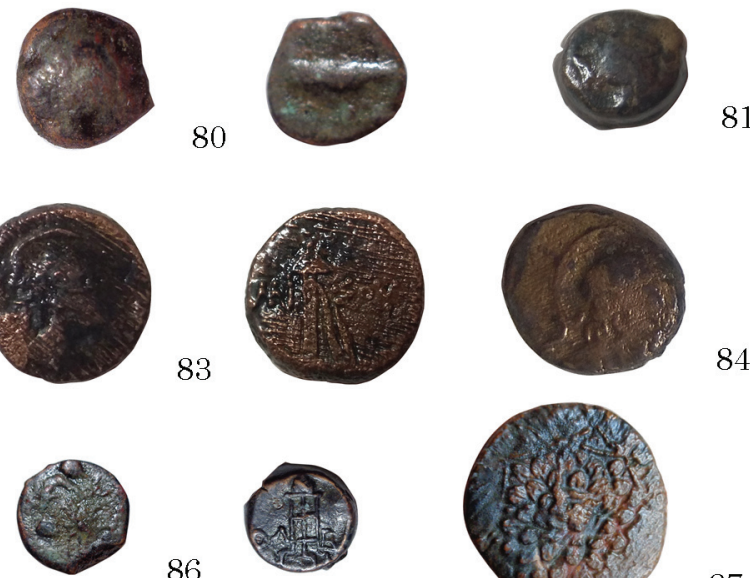

89

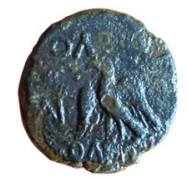

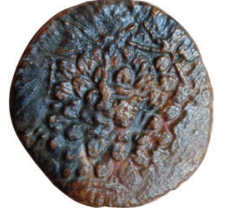

87

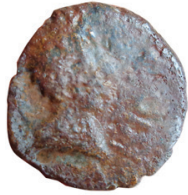

90
84

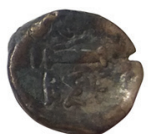

75

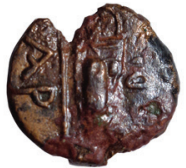

78

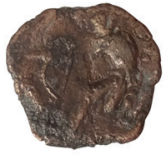

81
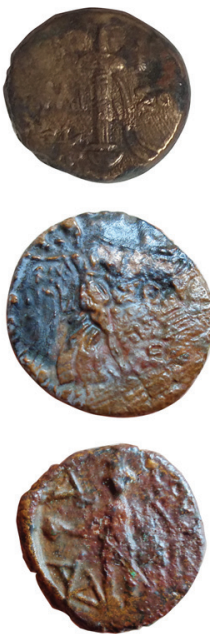
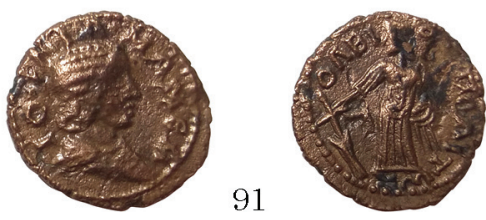

$1 \mathrm{~cm}$

hiatus of such large coins made of copper alloy in Olbia, were minted around the middle of the IV c. BC (Anokhin 2011, p. 46-53, fig. 233-243).

In addition, the pictorial programme also changes in comparison to the V c. BC, although with the constant reference to the dolphin there is at least one constant. However, if the dolphin appears very prominently in the form of the dolphin-shaped money, it now plays a much smaller role be it already on the big asses or later on the minted copper coins of the IV c. BC, now appearing only on the reverse of the individual coin series, whether it is in the claws of a sea eagle or, as on the small coins, accompanied by an ear of corn or a single grain.

Remarkable within the new pictorial programme of copper coins of the IV c. BC, which includes both the small currency and the somewhat larger and heavier coin series, is the turning towards Demeter as the most prominent deity on the obverse sides as well as the clear reference

P

to their sphere of influence, here however limited to the small coins, in the form of ears of grain. Possibly this can be explained by the revival of the Olbian Chora and the accompanying revival of the agricultural sector in about the same period, which was one of the most significant economic factors in Olbia during the entire IV c. BC (Kryzhitsky et. al. 1989, p. 96-152; Fornasier 2016, s. 103-105), which was promoted, among other things, by Athens' enormous demand for grain: since Attica was not able to supply its entire population with sufficient grain through its own agricultural sector, Athens was dependent on imports, which it obtained mainly from the Northern Black Sea region (Braund 2007, p. 5164; Moreno 2007, p. 69). This also affected Olbia, which obviously benefited economically from the Athens' need for grain and now resumed its own grain production after a longer hiatus during the V c. BC, which is clearly demonstrated by the cessation of settlement activity within its Chora 
(Bujskich 2006, p. 115-139). The re-emergence of the agricultural sector seems to have been reflected in the pictorial programme of the coins from the IV c. BC onwards, a practice not uncommon in the Greek Oikumene. Many Greek settlements refer to important economic sectors on their coins, such as fish, wine or cereals. Prominent examples are the images of whole tunas or even only parts of the fish on the coins of Cyzicus (Stolba 2008, p. 15), grains on some coins of Leontinoi (Talmatchi 2013, p. 315-317) or sturgeon on the coins of Olbia's eastern neighbor, Panticapaeum (Stolba 2008, p. 121-123).

Basically, it could be discussed whether the above-mentioned change within the Olbian monetary system in general was a reaction to a largescale reconsolidation of the Olbian settlement, which is reflected in a complete redesign of the Olbian urban space and the above-mentioned repopulation of its chora. Thus, towards the end of the $\mathrm{V}$ or the beginning of the IV c. BC, the socalled suburb was completely abandoned (Fornasier 2017, s. 48), its inhabitants will probably have settled in the settlements of the Chora or within the redesigned urban space. Apparently at the beginning, but definitely during the first half of the IV c. BC, this area was surrounded by an extensive city wall, which included the main plateau, i. e. the Olbian centre, the Lower City including the harbor on the banks of the Buh River, as well as also populated Terrace City between the plateau and the Lower City, in which the sector «T-4» relevant here is also located (fig. 1). It is possible that this reorganization of the polis, which apparently encompassed its entire territory, was accompanied by a general restructuring of Olbia, which was not only territorial, but also political and economic, and which was intended to ensure a previously unknown uniformity of the polis. The coins of the IV c. BC could also be usefully placed in this context, as they were characterized by a turn towards minted images, which both unified and facilitated their mass production, as well as by an accompanying uniform image programme. Moreover, this development in the Olbian monetary system chronologically goes hand in hand with the territorial changes of Olbia and seems to refer to them in terms of content - after all, they obviously show a direct reference to the resurrected agricultural sector. In addition, the coins of the IV c. BC, again concerning both the small currency and their larger counterparts, already at the beginning mostly show the inscribed reference to Olbia, which is also a novelty and underlines the official character of the minting of coins during the IV c. BC, whereas this was largely missing from the monetary objects of the V c. BC. Thus, the small coinage or, more generally, the coins minted in Olbia in the IV c. BC could also reflect the apparent new consolidation of the Olbian polis at the end of the $\mathrm{V}$ or beginning of the IV c. BC in the form of a specific type of object of Olbian origin, which could be an indicator that this reorganization was not only spatially reflected, but also affected the political and economic structures of Olbia.

A total of 42 monetary objects can be identified as Olbian small coins of the IV c. BC at the «T-4» sector during the campaigns of 2018-2020. However, it should be noted that in most cases it is difficult to catalogue the coins precisely, as their state of preservation often makes an exact identification difficult or even impossible. Nevertheless, due to the already described peculiarities - the mentioned small dimensions as well as the use of copper alloy for the production - their affiliation to the Olbian small coins can at least be addressed as objects of the IV c. BC with Olbian origin, even if an exact allocation is not possible.

Finally, it is worth mentioning a peculiarity of the Olbian small coins, which makes them stand out in comparison with other Greek poleis during the IV c. BC. Basically, most Greek cities already minted primarily silver coins at the end of the VI c. or at the beginning of the V c. BC, which were mostly based on a Greek weight standard. The two larger neighboring poleis of Olbia, Istria and Panticapaeum, also minted silver coins as early as the beginning of the $\mathrm{V}$ c. BC (Stingl 2005, s. 120 - 121). Coins made of copper or copper alloy usually appear much later, mainly from the second half of the IV c. BC onwards, but they are then usually much heavier and larger than the Olbian small coins. Thus, this genus of Olbian money makes it difficult to draw an analogy with the coins of other Greek poleis at the same time, both inside and outside the Northern Black Sea area. Only the cast "wheel» coins from Istria can be compared in function and dimensions with the Olbian coins (Anokhin 2011, p. 42-43, $\mathrm{N}$ 188), but they remain the absolute exception. This leads to the conclusion that the Olbian coinage had a small function change at a very early stage, since the purchase value or material value of the Olbian coins is not expected to be particularly high. There is a clear difference here to the silver coinage of the other Greek cities at the same time, which, due to their material and weight, were probably used for larger transactions, for example for foreign trade or in exchange for larger quantities of goods, while for smaller transactions barter was probably still used. This may already have been replaced, or at least complemented on a large scale, by the introduction of the small copper currency in Olbia. This may have been derived from the usage of arrowheadshaped money (Anokhin 2011, p. 30-31, N 153) or, in Olbia and its territory, from the dolphinshaped coins, which, in view of the material used and the, at least in part, also quite low weight, probably fulfilled a function quite comparable to the Olbian small coins and were later, after the reorganization of the polis, successively replaced by them. Thus, Olbia can probably be described 
as one of the cradles of change as in small coinage not in changing something, maybe small currency would be better.

Since the last third of the IV c. BC in Olbia, coins are issued with the image of the river deity Borysthenes. The borysthenes coins found at the «T-4» site - well-preserved - have trims: $\Phi$, AP, $\mathrm{EY}, \Delta \mathrm{H}$ (fig. 8: 73, 75-77), belong to the groups I-a, II-c, V-c, VII, allocated by P. O. Karyshkovskyi (Карышковский 2003, с. 168-174), and cover the entire chronological period of their existence from 330 to $230 \mathrm{BC}$ (Appendix). The differences between them lie both in the weight category and in stylistic features. Thus, in a specimen of the first group (fig. 8: 73), the ear of the river deity is covered with large locks of hair, the horn is turned forward, a nose and an eye are monolithically merged with the general profile. On coins of other groups, with the trims $\mathrm{AP}, \mathrm{EY}$ and $\Delta \mathrm{H}$ (fig. 8: 74, 76, 77), the image of Borysthenes conveys thin curling locks of hair that do not cover the ear, with a well-defined earlap. Beard curls are marked in the same way. The nose, lips and eyes are highlighted with separate underlined lines. Coin weights also vary between the larger categories in the first and last groups, and the smaller denominations in the middle groups.

A coin with the head of Artemis on the obverse, and a bow on the reverse, with the inscription $\mathrm{B} \Sigma \mathrm{E}$ (fig. 8: 81), which is an abbreviation for Băoŭ $\lambda \varepsilon \dot{s}$ - the official name of the Olbian «king», a priest for life elected (Зограбр 1951, с. 134), dated by 180-170 ВC (Карышковский 1988, c. $97 ; 2003$, с. 189 ; Анохин 1989, с. 50-51), and belongs to a series of coins that supplanted out of circulation earlier copper with numerous countermarks.

The latest specimens of coins of the pre-Getic period of Olbia are represented by coins of the Asia Minor city of Amis (fig. 8: 83-84, 87), which are dated by the end of the II - first half of the I c. BC (Wroth 1889 , p. 17, 19, No. 40-43, 6971, pl. III: 5; IV: 1; Зограф 1940, с. 293). Their appearance is associated with the inclusion of Olbia in the Pontic kingdom of Mithridates VI Eupator (Ростовцев 1907, с. 21-27; IOSPE I ${ }^{2} 35$ ), in particular with the deployment of a Pontic garrison in the city (Виноградов 1989, с. 254-258; Крапивина, Диатроптов 2005, с. 69; Макаров 2005 , c. 241), or the resettlement to the Olbian region of the suburb inhabitants of Sinope Armene (Жебелев 1940, с. 293-299), who brought with them coins of the Pontic kingdom cities (Зограd 1940, c. 299) ${ }^{1}$.

According to P. O. Karyshkovskyi, among the coins of Amis, the most numerous tetrachalks with the image of the Ares head in a helmet and a sword in a sheath belong to the third chronological group of coins of Pontus and Paphlagonia in Olbia,

1. The latter version was later criticized (for more details see: Виноградов 1989, с. 254-255). and are dated by 111-105 ВC (Карышковский 2003, c. 249). The fourth chronological group of these coins includes tetrachalks with the image of the Aegis with the Gorgon's head on the obverse, and the walking Nike on the reverse, presented in one item at the «T-4» site (fig. 8: 87) with the dating 105-90 ВС (Карышковский 2003, c. 249 ), or $85-65$ BC (SNG IX 1177-1191). The total number of coins of the city of Amis in Olbia, taking into account the latest research in the southeastern part of the Upper City, should already be in the hundreds of coins.

To the first two decades of the I c. BC there can be included the following coins: with the head of Apollo on the obverse, and a quiver between the stars on the reverse (fig. 8: 85), as well as with the image of a dolphin and a star between the caps of the Dioscuri on the obverse, and a tripod on the reverse (fig. 8: 86). Thus, these items complete the numismatic series of coins from the excavations of the «T-4» sector, which belongs to the stage before the Getan devastation of Olbia, which took place in the middle of this century.

Roman period. Coins of the Roman period found at the «T-4» are represented by the earliest and latest urban numismatic monuments of postGetan Olbia. So, in the process of research, two copper coins were found with the head of Zeus in a dotted circular rim on the obverse, and the image of an eagle with outstretched wings, the ПA monogram and the inscription $\mathrm{O} \Lambda \mathrm{BIO} \Pi \mathrm{OO} \Lambda \mathrm{EIT} \omega \mathrm{N}$ on the reverse (fig. 8: 88, 89). One of them on the head of Zeus has a countermark in the shape of a caduceus. According to P. O. Karyshkovskyi, they belong to the third and fourth series of coins of the Zeus / eagle type, and are dated by the mid 50 - early 60s of the I c. AD (Карышковский 1982 , с. $19 ; 2003$, с. 194 , табл. XXIb: 5-15). According to V. A. Anokhin, who starts from the socalled Olbian era (Анохин 1971), their dating varies within the end of 40 - early 50s $\mathrm{AD}$ (Анохин 1989 , c. $63-64)$.

Olbian dupondius with the head of Apollo and the inscription $\mathrm{O} \Lambda \mathrm{BIO \Pi O}$ on the obverse, and Apollo with a round bowl and a bow in his hands, and the inscription $\triangle \mathrm{A} \triangle \mathrm{OC} \mathrm{CATY}$ on the reverse (fig. 8: 90) is dated by 180-192 AD (Карышковский 1988, с. 123; Анохин 1989, c. 73). The inscription on the reverse is compared with the name of Dada, the son of Satyr, known from the Olbian epigraphy (IOSPE I ${ }^{2} 281$ ), during archonatus of whose this coin emission was issued.

In 2019, an excavation extension was carried out in the northern part of the «T-4» site, in which materials from the I-III c. AD were revealed. In it, at a depth of $1.25 \mathrm{~m}$ from the level of the modern day surface, the tressis of Julia Mamaea $(222-235 \mathrm{AD})$ of the Olbian coinage, with the image of the head of the empress on the obverse to the right, and the goddess Tyche with a steering oar and a cornucopia on the reverse, was disco- 
vered (fig. 8: 91). Olbia began minting coins with the images of the Roman imperial family since the time of Septimius Severus, which was associated with the entry of the city into the Roman Empire (Карышковский 1988, с. 124-126). This item belongs to the last series of monetary units of the Olbian autonomous minting (Карышковский 1988 , с. 127 ; 2003 , с. 264 ; Анохин 1989, с. 74 ; 2011, c. 92).

To conclude, at this stage of research, the numismatic material from the excavations at the "T-4» site in Olbia are dated from the second half of the VI c. BC, and until the end of the Olbian coinage in the second third of the III c. AD, that is, cover all the main chronological periods of Olbia's existence.

\section{APPENDIX}

\section{COINS FOUND IN OLBIA AT THE «T-4» SECTOR DURING 2018-2020 (NO DOLPHIN-SHAPED COINS)}

49. (Inv. N O-2018/T-4/377). Copper coin, obverse: wheel; reverse: I $\Sigma$ T. Dating: V-IV c. BC. Weight: 1.19 g. Diameter: $12 \mathrm{~mm}$. Place of coinage: Istria. Zaginaylo 1991, s. 57-59.

50 (Inv. N O-2020/T-4/143). Copper coin, obverse: head of Demeter to the right; reverse: eagle on the dolphin to the left, $\mathrm{O} \Lambda \mathrm{BIO}$ from above, $\mathrm{B} \Sigma \mathrm{E}$ at the bottom. Dating: ca. 380—360 BC. Weight: 8.46 g. Diameter: $19 \mathrm{~mm}$. Place of coinage: Olbia. Similar to Anokhin 1989, 2011, N 199-213.

51 (Inv. N O-2018/T-4/834). Copper coin, obverse: head of Demeter to the right; reverse: eagle on the dolphin, OAP from above. Dating: ca. 380-360 BC. Weight: 0.52 g. Diameter: $8 \mathrm{~mm}$. Place of coinage: Olbia. Anokhin 1989, N 58; 2011, N 218.

52 (Inv. N O-2018/T-4/1405). Copper coin, obverse: head of Demeter to the right; reverse: eagle on the dolphin to the right, HPEY $\Phi$ at the bottom (retrograde). Dating: ca. 380-360 BC. Weight: 2.09 g. Diameter: $17 \mathrm{~mm}$. Place of coinage: Olbia. Anokhin 1989, N 42.

53 (Inv. N O-2019/T-4/790). Copper coin, obverse: head of Demeter to the left; reverse: eagle on the dolphin to the left, O $\Lambda$ BIO from above. Dating: ca. 380360 BC. Weight: $1.9 \mathrm{~g}$. Diameter: $15 \mathrm{~mm}$. Place of coinage: Olbia. Anokhin 2011, N 192.

54 (Inv. N O-2019/T-4/791). Copper coin, obverse: head of Demeter to the right; reverse: eagle on the dolphin to the right, $\mathrm{O} \Lambda \mathrm{BIO}$ at the bottom. Dating: ca. 380-360 BC. Weight: 3.8 g. Diameter: $17 \mathrm{~mm}$. Place of coinage: Olbia. Anokhin 1989, N 30; 2011, N 200, 213.

55 (Inv. N O-2019/T-4/1197). Copper coin, obverse: head of Demeter to the right; reverse: eagle on the dolphin to the right, OABIO from above. Dating: ca. 380360 BC. Weight: $1.8 \mathrm{~g}$. Diameter: $15 \mathrm{~mm}$. Place of coinage: Olbia. Anokhin 1989, N 30; 2011, N 200, 213.

56 (Inv. N O-2020/T-4/68). Copper coin, obverse: head of Demeter to the right; reverse: dolphin to the right, ear of corn, $\mathrm{O} \Lambda \mathrm{BIO}$ at the bottom. Dating: ca. 380 -360 BC. Weight: 1.07 g. Diameter: $13 \mathrm{~mm}$. Place of coinage: Olbia. Anokhin 1989, N 48.

57 (Inv. N O-2020/T-4/743). Copper coin, obverse: head of Demeter to the right; reverse: eagle on the dol- phin, $\mathrm{O} \Lambda \mathrm{BIO}$ at the bottom. Dating: ca. 380-360 BC. Weight: 0.38 g. Diameter: $8 \mathrm{~mm}$. Place of coinage: Olbia. Anokhin 1989, N 58; 2011, N 218.

58 (Inv. N O-2019/T-4/788). Copper coin, obverse: head of Demeter to the right; reverse: dolphin to the right, ear of corn, $\mathrm{O} \Lambda \mathrm{BIO}$ at the bottom (retrograde). Dating: ca. 380-360 BC. Weight: $0.3 \mathrm{~g}$. Diameter: $7 \mathrm{~mm}$. Place of coinage: Olbia. Anokhin 1989, N 58; 2011, N 218.

59 (Inv. N O-2019/T-4/430). Copper coin, obverse: head of Demeter to the right; reverse: eagle on the dolphin to the right, OABIO from above. Dating: ca. 380360 BC. Weight: $7.5 \mathrm{~g}$. Diameter: $15 \mathrm{~mm}$. Place of coinage: Olbia. Anokhin 2011, N 211.

60 (Inv. N O-2018/T-4/375). Copper coin, obverse: head of goddess Tuche in crown of the shape of tower to the right; reverse: bent archer to the left. Dating: ca. 360-350 BC. Weight: 1.19 g. Diameter: $13 \mathrm{~mm}$. Place of coinage: Olbia. Anokhin 1989, N 59.

61 (Inv. N O-2020/T-4/870). Copper coin, obverse: head of goddess Tuche in crown of the shape of tower to the right; reverse: bent archer to the left. Dating: ca. 360 -350 BC. Weight: $1.88 \mathrm{~g}$. Diameter: $14 \mathrm{~mm}$. Place of coinage: Olbia. Anokhin 1989, N 59.

62 (Inv. N O-2019/T-4/1199). Copper coin, obverse: forepart of bull on dolphin to the left; reverse: trident between two dolphins swimming upwards. Dating: 387-340 BC. Weight: 2.0 g. Diameter: $14 \mathrm{~mm}$. Place of coinage: Byzantium. SNG IX 14-20.

63 (Inv. N O-2018/T-4/833). Copper coin, obverse: head of Demeter to the left; reverse: eagle on the dolphin to the left, $\mathrm{O} \Lambda \mathrm{BIO}$ at the bottom. Dating: ca. $330-325$ BC. Weight: $1.62 \mathrm{~g}$. Diameter: $19 \mathrm{~mm}$. Place of coinage: Olbia. Anokhin 1989, N 99, 100; 2011, N 271, 272.

64 (Inv. N O-2018/T-4/26). Copper coin, obverse: head of Apollo to the right; reverse: eagle on the dolphin to the right (?), O $\Lambda \mathrm{BIO}$ at the bottom. Dating: ca. $325-320$ BC. Weight: 0.91 g. Diameter: $8 \mathrm{~mm}$. Place of coinage: Olbia. Anokhin 1989, N 113; 2011, N 284.

65 (Inv. N O-2018/T-4/1432). Copper coin, obverse: head of Apollo to the right; reverse: eagle on the dolphin to the right, O $\triangle \mathrm{BIO}$ at the bottom. Dating: ca. 325320 BC. Weight: 0.51 g. Diameter: $7.7 \mathrm{~mm}$. Place of coinage: Olbia. Anokhin 1989, N 113; 2011, N 284.

66 (Inv. N O-2018/T-4/1924). Copper coin, obverse: head of Apollo to the right; reverse: eagle on the dolphin to the right, bow and grain from above, $\mathrm{O} \Lambda \mathrm{BIO}$ at the bottom. Dating: ca. 325-320 BC. Weight: 1.36 g. Diameter: $10 \mathrm{~mm}$. Place of coinage: Olbia. Anokhin 1989, N 113; 2011, N 284.

67 (Inv. N O-2019/T-4/253). Copper coin, obverse: head of Apollo to the right; reverse: eagle on the dolphin to the right, bow and grain from above, O $\triangle \mathrm{BIO}$ at the bottom. Dating: ca. 325-320 BC. Weight: $0.7 \mathrm{~g}$. Diameter: $8 \mathrm{~mm}$. Place of coinage: Olbia. Anokhin 1989, N 113; 2011, N 284.

68 (Inv. N O-2019/T-4/431

Copper coin, obverse: head of Demeter to the left; reverse: eagle on the dolphin to the left, O $\Lambda \mathrm{BIO}$ at the bottom. Dating: ca. 330-325 BC. Weight: $1.5 \mathrm{~g}$. Diameter: $12 \mathrm{~mm}$. Place of coinage: Olbia. Anokhin 1989, N 99, 100; 2011, N 271, 272.

69 (Inv. N O-2019/T-4/787). Copper coin, obverse: head of Apollo to the right; reverse: eagle on the dolphin to the right, bow and grain from above, O $\Lambda \mathrm{BIO}$ at the bottom. Dating: ca. 330-325 BC. Weight: 0.5 g. Diameter: $7 \mathrm{~mm}$. Place of coinage: Olbia. Anokhin 1989, N 113; 2011, N 284. 
70 (Inv. N O-2019/T-4/477). Copper coin, obverse: head of Demeter to the left; reverse: eagle on the dolphin to the left, $\mathrm{O} \Lambda \mathrm{BIO}$ at the bottom. Dating: ca. $330-325$ BC. Weight: 1.7 g. Diameter: $13 \mathrm{~mm}$. Place of coinage: Olbia. Anokhin 1989, N 99, 100; 2011. N 271, 272.

71 (Inv. N O-2019/T-4/1351). Copper coin, obverse: head of Apollo to the right; reverse: eagle on the dolphin to the left, bow and grain from above, $\mathrm{O} \Lambda \mathrm{BIO}$ at the bottom. Dating: ca. 325-320 BC. Weight: 0.8 g. Diameter: $9 \mathrm{~mm}$. Place of coinage: Olbia. Anokhin 1989, N 113; 2011, N 284.

72 (Inv. N O-2018/T-4/1433). Copper coin, obverse: head of Demeter to the right; reverse: eagle on the dolphin to the left, ear of corn, O $\Lambda$ BIO at the bottom. Dating: ca. 320-315 BC. Weight: 0.42 g. Diameter: $7.1 \mathrm{~mm}$. Place of coinage: Olbia. Anokhin 1989, N 118.

73 (Inv. N O-2018/T-4/1430). Copper coin, borysthenes, obverse: head of Borysthenes to the left; reverse: OABIO, quiver, ceremonial ax, $\Phi$ at the bottom. Dating: ca. 330300 BC. Weight: $8.32 \mathrm{~g}$. Diameter: $20.4 \mathrm{~mm}$. Place of coinage: Olbia. Karyshkovskiy 2003, p. 168-174.

74 (Inv. N O-2020/T-4/144). Copper coin, borysthenes, obverse: head of Borysthenes to the left; reverse: quiver, ceremonial ax, $\mathrm{O} \Lambda \mathrm{BIO}$ on the right. Dating: 330 -230 BC. Weight: 3.34 g. Diameter: $18 \mathrm{~mm}$. Place of coinage: Olbia. Karyshkovskiy 2003, p. 168-174.

75 (Inv. N O-2020/T-4/868). Copper coin, borysthenes, obverse: head of Borysthenes to the left; reverse: quiver, ceremonial ax, $\mathrm{O} \Lambda \mathrm{BIO}$ on the right, $\mathrm{AP}$ on the left. Dating: ca. 290-250 BC. Weight: 2.26 g. Diameter: $19 \mathrm{~mm}$. Place of coinage: Olbia. Karyshkovskiy 2003 , p. $168-174$.

76 (Inv. N O-2020/T-4/142). Copper coin, borysthenes, obverse: head of Borysthenes to the left; reverse: quiver, ceremonial ax, $\mathrm{O} \Lambda \mathrm{BIO}$ on the right, $\mathrm{EY}$ on the left. Dating: ca. 280-250 BC. Weight: 7.15 g. Diameter: $20 \mathrm{~mm}$. Place of coinage: Olbia. Karyshkovskiy 2003 , p. $168-174$.

77 (Inv. N O-2020/T-4/869). Copper coin, borysthenes, obverse: head of Borysthenes to the left; reverse: quiver, ceremonial ax, $\mathrm{O} \Lambda \mathrm{BIO}$ on the right, $\Delta \mathrm{H}$ on the left. Dating: ca. 240-230 BC. Weight: 7.85 g. Diameter: $20 \mathrm{~mm}$. Place of coinage: Olbia. Karyshkovskiy 2003 , p. $168-174$.

78 (Inv. N O-2019/T-4/432). Copper coin, obverse: head of Apollo to the right; reverse: bent archer to the left. Dating: 260-250 BC. Weight: $2.7 \mathrm{~g}$. Diameter: $15 \mathrm{~mm}$. Place of coinage: Olbia. Anokhin 1989, N 233; 2011, N 406.

79 (Inv. N O-2020/T-4/783). Copper coin, obverse: head of Apollo to the right; reverse: bent archer to the left. Dating: 270-260 BC. Weight: $0.51 \mathrm{~g}$. Diameter: $8 \mathrm{~mm}$. Place of coinage: Olbia. Anokhin 2011, N 405-407.

80 (Inv. N O-2020/T-4/681). Copper coin, obverse: head of Heracles (?) to the right; reverse: cudgel, OABIO at the bottom. Dating: ca. 200-190 BC. Weight: $0.47 \mathrm{~g}$. Diameter: $8 \mathrm{~mm}$. Place of coinage: Olbia. Frolova Abramzon 2005, pl. 90: 1-4

81 (Inv. N O-2019/T-4/785). Copper coin, obverse: head of Artemis to the left; reverse: quiver, B $\Sigma \mathrm{E}$ at the bottom. Dating: $180-170$ BC. Weight: $3.4 \mathrm{~g}$. Diameter: $12 \mathrm{~mm}$. Place of coinage: Olbia. Anokhin 2011, N 488.

82 (Inv. N O-2018/T-4/470). Copper coin, obverse: head of Apollo to the right; reverse: eagle on the dolphin to the right, $\mathrm{O} \Lambda \mathrm{BIO}$ at the bottom. Dating: ca. $170-160$ BC. Weight: 5.30 g. Diameter: $26 \mathrm{~mm}$. Place of coinage: Olbia. Anokhin 1989, N 310.
83 (Inv. N O-2019/T-4/792). Copper coin, tetrachalkos, obverse: head of young Ares to the right, wearing crested helmet; reverse: sword in sheath, with strap, AMI-EOY. Dating: end of II c. - beginning of I c. BC. Weight: $6.6 \mathrm{~g}$. Diameter: $18 \mathrm{~mm}$. Place of coinage: Amis. SNG IX 1147-1152.

84 (Inv. N O-2019/T-4/1045). Copper coin, tetrachalkos, obverse: head of young Ares to the right, wearing crested helmet; reverse: sword in sheath, with strap, AMI-LOY. Dating: end of II c. - beginning of I c. BC. Weight: $7.7 \mathrm{~g}$. Diameter: $18 \mathrm{~mm}$. Place of coinage: Amis. SNG IX 1147-1152.

85 (Inv. N O-2019/T-4/572). Copper coin, obverse: head of Apollo to the right; reverse: quiver, stars. Dating: $90-80$ BC. Weight: 1.8 g. Diameter: $12 \mathrm{~mm}$. Place of coinage: Olbia. Anokhin 1989, N 337; 2011, N 514.

86 (Inv. N O-2020/T-4/145). Copper coin, obverse: dolphin to the left and the star between caps of Dioscuri; reverse: tripod, $\mathrm{O} \Lambda \mathrm{BI}$ in the middle. Dating: ca. 9080 BC. Weight: $2.49 \mathrm{~g}$. Diameter: $11 \mathrm{~mm}$. Place of coinage: Olbia. Anokhin 1989, N 336; 2011, N 515.

87 (Inv. N O-2018/T-4/1406). Copper coin, tetrachalkos, obverse Aegis with Gorgon's head in centre; reverse: Nike advancing right with shouldered palm branch, AMI-EOY. Dating: 85-65 BC. Weight: $5.71 \mathrm{~g}$. Diameter: $21 \mathrm{~mm}$. Place of coinage: Amis. SNG IX 1177-1191.

88 (Inv. N O-2019/T-4/896). Copper coin, assarius, obverse: head of Zeus to the right with over-minting of caduceus; reverse: monogram ПА, eagle, O $\Lambda \mathrm{BIO}$ $\Pi O \Lambda E I T \omega N$. Dating: middle of 50s AD. Weight: $2.9 \mathrm{~g}$. Diameter: $18 \mathrm{~mm}$. Place of coinage: Olbia. Karyshkovskiy 1982 , s. $14-23$.

89 (Inv. N O-2018/T-4/417). Copper coin, assarius, obverse: head of Zeus to the right; reverse: monogram $\Pi$ A, eagle, O $\Lambda$ BIO ПO $\Lambda$ EIT $\omega N$. Dating: end of $50 \mathrm{~s}$ - beginning of $60 \mathrm{~s} \mathrm{AD}$. Weight: $3.69 \mathrm{~g}$. Diameter: $18.8 \mathrm{~mm}$. Place of coinage: Olbia. Karyshkovskiy 1982, s. $14-$ 23.

90 (Inv. N O-2018/T-4/922). Copper coin, dupondius, obverse: head of Apollo to the right, OАBIOПO; reverse: Apollo with bow and arrow, $\triangle \mathrm{A} \triangle \mathrm{OC}$ CATY. Dating: ca. 180-192 AD. Weight: 5.13 g. Diameter: $21 \mathrm{~mm}$. Place of coinage: Olbia. Anokhin 1989, N 382; 2011, N 549.

91 (Inv. N O-2019/T-4/617). Copper coin, tressis, obverse: head of Julia Mamaea to the right; reverse: goddess Tuche, which holds rudder and cornucopia to the left, O $\Lambda$ BIO ПO $\Lambda$ EIT $\omega N$ in circle, T (inverted). Dating: 222-235 AD. Weight: 4.6 g. Diameter: $18 \mathrm{~mm}$. Place of coinage: Olbia. Anokhin 1989, N 397; 2011, N 567.

\section{ЛIТЕРАТУРА}

Анохин, В. А. 1971. К вопросу об ольвийской эре. Нулизматика и собрагистика, 4, с. 87-91.

Анохин, В. А. 1989. Монеть античных городов Северо-Западного Причерноморья. Киев: Наукова думка.

Анохин, В. А. 2011. Античные лонеты Северного Причернолорья. Каталог. Киев: Стилос.

Буйских, А. В., Форнасье, Й., Козленко, Р. А., Чечулина, И. А. 2020. Отчет о раскопках на участке T-4 в Ольвии в 2019 году. НА IA НАН України, фр. 64.

Виноградов, Ю. Г. 1984. Декрет в честь Антестерия и кризис Ольвийского полиса в эпоху эллинизма. Вестник древней истории, 1, с. 51-80. 
Виноградов, Ю. Г. 1989. Политическая история Ольвийского полиса VII-Iвв. до н. э.: историкоэпиграббиеское исследование. Москва: Наука.

Жебелев, С. А. 1940. Ольвия и Мифрадат Евпатор (IOSPE, I2, 35). В: Ячменев, Н. И. (ред.). Ольвия. 1. Киев: АН УССР, с. 281-292.

Загинайло, А. Г. 1991. Литые монеты из Никония (к вопросу об экономических связях города в VI-IV вв. до н. э.). В: Ванчугов, В. П. (ред.). СевероЗападное Причерноморье - контактная зона древних культур. Киев: Наукова думка, с. 52-61.

Зограф, А. Н. 1940. Находки понтийских монет мифрадатовского времени в Ольвии. В: Ячменев, Н. И. (ред.). Ольвия. 1. Киев: АН УССР, с. 293-299.

Зографр, А. Н. 1951. Античные монеты. Материалы и исследования по археологии СССР, 16. Москва.

Золотарьов, М. I. 1997. Новий скарб ольвійських дельфіноподібних монет з розкопок на о. Березань. Археологія, 4, с. 141-144.

Карышковский, П. О. 1960. Заметки по нумизматике античного Причерноморья. 4-6. Вестник древней истории, 3, с. 132-141.

Карышковский, П. О. 1982. Ольвия и Рим в І в. н. э. В: Гудкова, А. В. (ред.). Палятники рилиского и средневекового времени в Северо-Западном Причернолорье. Киев: Наукова думка, с. 6-28.

Карышковский, П. О. 1988. Монеты Ольвии. Очерк денежного обращения Северо-Западного Причерноморья в античную эпоху. Киев: Наукова думка.

Карышковский, П. О. 1999. Ольвийские монеты: производство и метрология. Stratum plus, 6, с. 2067.

Карышковский, П. О. 2003. Монетное дело и денежное обращение Ольвии (VI в. до н. э. - IV в. н. э.). Одесса: А. С. Фридман.

Крапивина, В. В., Диатроптов, П. Д. 2005. Надпись наместника Митридата VI Евпатора из Ольвии. Вестник древней истории, 1, с. 67-73.

Крыжицкий, С. Д., Буйских, С. Б., Бураков, А. В., Отрешко, В. М. 1989. Сельская округа Ольвии. Киев: Наукова думка.

Макаров, И. А. 2005. Эпитафия командира армянских лучников из Херсонеса Таврического. Херсонесский сборник, 14, с. 239-248.

Рубан, В. В. 1982. О хронологическом соотношении литых стрело- и дельфиновидных бронзовых монет на территории Нижнего Побужья. В: Янин, В. Л. (ред.). Нумизматика античного Причернолорья. Киев: Наукова думка, с. 15-20.

Рубан, В. В., Урсалов, В. Н. 1986. История денежного обращения на сельской территории Борисфениды и Ольвии догетского времени. Вестник древней истории, 4, с. 31-53.

Ростовцев, М. И. 1907. Митридат Понтийский и Ольвия. Известия археологической колиссии, 23, c. 21-27.

Секерская, Н. М., Булатович, С. А. Монетные находки из Никония (1964-2010 гг.). В: Бруяко, И. В. (ред.). Записки відділу нумізматики $i$ торевтики Одеського археологічного музею. Одеса: СМИЛ, c. 27-38.

Снытко, И. А., Туровский, Е. Я. 2000. О монетах Ольвии и Херсонеса с изображениями стрелков из лука. Херсонесский сборник, 10, с. 399-404.

Фролова, Н. А., Абрамзон, М. Г. 2005. Монетьь Ольвии в собрании Государственного исторического музея. Каталог. Москва: РоссПЭн.

Харко, В. П. 1964. Монеты из раскопок Ольвии в 1946-1947 гг. В: Гайдукевич, В. Ф. (ред.). Ольвия.
Теменос и агора. Москва; Ленинград: Наука, с. 321379.

Braund, D. 2007. Black Sea Grain for Athens? From Herodotus to Demosthenes. Black Sea Studies, 6, p. 3968.

Bujskich, S. B. 2006. Die Chora des Pontischen Olbia: Die Hauptetappen der räumlich-strukturellen Entwicklung. Black Sea Studies, 4, S. 115-139.

Chistov, D. 2019. The Chronology of Arrowhead and Dolphin-Shaped Monetary Signs from Berezan. In: Tsetskhladze, G. R., Atasoy, S. (eds.). Settlements and Necropolis of the Black Sea and its Hinterland in Antiquity. Select Papers from the Third International Conference "The Black Sea in Antiquity and Tekkeköy: An Ancient Settlement on the Southern Black Sea Coast", 27-29 October 2017. Tekkeköy: Archaeopress Archaeology, p. 99-107.

Fornasier, J. 2016. Die griechische Kolonisation im nördlichen Schwarzmeerraum vom 7. bis 5. Jahrhundert v. Chr. Archäologie in Eurasien, 32. Bonn: Habelt.

Fornasier, J. , Bujskich, A. V., Kuz'miščev, A. G., Patzelt, A., Helfert, M., Kratzsch, N. 2017. Vor den Toren der Stadt. Deutsch-ukrainische Forschungen in der Vorstadt von Olbia Pontike. Archäologischer Anzeiger, 1, S. 19-61.

Moreno, A. 2007. Athenian Wheat-Tsars: Black Sea Grain and Elite Culture. Black Sea Studies, 6, p. 69-84.

Reuter, A. 2021. Die Münzen der deutsch-ukrainischen Grabungen 2015-2019 - ein Überblick. In: Fornasier, J. (ed.). An den Ufern des Bug - Internationale Fachtagung anlässlich des Jubiläums: 5 Jahre deutsch-ukrainische Ausgrabungen in Olbia Pontike Goethe Universität Frankfurt am Main. Frankfurt am Main, Germany, 7-9 Oktober 2019, in print.

Stingl, T. 2005. Frühe bronzene Geldformen im Nordwestlichen Schwarzmeerraum. Internationale Archäologie, 6, S. 119-123.

Stolba, V. F. 2008. Fish and Money: Numismatic Evidence for Black Sea Fishing. Black Sea Studies, 2, p. 115-132.

Stolba, V. F. 2015. "Archers» of the Blessed City: City's Deliverance in the Coinage of Early Hellenistic Olbia. Notae Numismaticae, X, p. 43-58.

Talmatchi, G. 2013. New Possible Approach on the Significance of Arrowhead-Shaped Monetary Signs Especially Cast for Trade Purposes. Peuce, IX, p. 307-326.

Wroth, W. 1889. A Catalogue of Greek Coins. Pontus, Paphlagonia, Bithynia, and the Kingdom of Bosporus. London: Longmans \& Co.

\section{REFERENCES}

Anokhin, V. A. 1971. K voprosu ob olviiskoi ere. Numizmatika $i$ sfragistika, 4, s. 87-91.

Anokhin, V. A. 1989. Monety antichnykh gorodov SeveroZapadnogo Prichernomoria. Kiev: Naukova dumka.

Anokhin, V. A. 2011. Antichnye monety Severnogo Prichernomoria. Katalog. Kiev: Stilos.

Buiskikh, A. V., Fornase, I., Sheiko, I. N., Kozlenko, R. A., Chechulina, I. A. 2020. Otchet o raskopkakh na uchastke T-4 v Olvii v 2019 godu. NA IA NAN Ukrainy, f. 64.

Vinogradov, Iu. G. 1984. Dekret v chest Antesteriia i krizis Olviiskogo polisa v epokhu ellinizma. Vestnik drevnei istorii, 1, s. $51-80$

Vinogradov, Iu. G. 1989. Politicheskaia istoriia Olviiskogo polisa VII-I vv. do n. e.: istoriko-epigraficheskoe issledovanie. Moskva: Nauka.

Zhebelev, S. A. 1940. Olviia i Mifradat Evpator (IOSPE, I2, 35). In: Iachmenev, N. I. (ed.). Olviia. 1. Kiev: AN USSR, s. $281-292$. 
Zaginailo, A. G. 1991. Litye monety iz Nikoniia (k voprosu ob ekonomicheskikh sviaziakh goroda v VI-IV vv. do n. e.). In: Vanchugov, V. P. (ed.). Severo-Zapadnoe Prichernomorekontaktnaia zona drevnikh kultur. Kiev: Naukova dumka, s. $52-61$.

Zograf, A. N. 1940. Nakhodki pontiiskikh monet mifradatovskogo vremeni v Olvii. In: Iachmenev, N. I. (ed.). Olviia. 1. Kiev: AN USSR, s. 293-299.

Zograf, A. N. 1951. Antichnye monety. Materialy i issledovaniia po arkheologii SSSR, 16. Moskva.

Zolotarov, M. I. 1997. Novyi skarb olviiskykh delfinopodibnykh monet z rozkopok na o. Berezan. Arkheolohiia, 4, s. 141-144

Karyshkovskii, P. O. 1960. Zametki po numizmatike antichnogo Prichernomoria. 4-6. Vestnik drevnei istorii, 3, s. $132-141$.

Karyshkovskii, P. O. 1982. Olviia i Rim v I v. n. e. In Gudkova, A. V. (ed.). Pamiatniki rimskogo $i$ srednevekovogo vremeni $v$ Severo-Zapadnom Prichernomore. Kiev: Naukova dumka, s. 6-28.

Karyshkovskii, P. O. 1988. Monety Olvii. Ocherk denezhnogo obrashcheniia Severo-Zapadnogo Prichernomoria $v$ antichnuiu epokhu. Kiev: Naukova dumka.

Karyshkovskii, P. O. 1999. Olviiskie monety: proizvodstvo i metrologiia. Stratum plus, 6, s. 20-67.

Karyshkovskii, P. O. 2003. Monetnoe delo $i$ denezhnoe obrashchenie Olvii (VI v. do n. e. $-I V v$. n. e.). Odessa: A. S. Fridman.

Krapivina, V. V., Diatroptov, P. D. 2005. Nadpis namestnika Mitridata VI Evpatora iz Olvii. Vestnik drevnei istorii, 1, s. $67-73$.

Kryzhitskii, S. D., Buiskikh, S. B., Burakov, A. V., Otreshko, V. M. 1989. Selskaia okruga Olvii. Kiev: Naukova dumka.

Makarov, I. A. 2005. Epitafiia komandira armianskikh luchnikov iz Khersonesa Tavricheskogo. Khersonesski sbornik, 14, s. 239-248.

Ruban, V. V. 1982. O khronologicheskom sootnoshenii litykh strelo- i delfinovidnykh bronzovykh monet na territori Nizhnego Pobuzhia. In: Ianin, V. L (ed), Numizmatika antichnogo Prichernomoria. Kiev: Naukova dumka, s. 15-20.

Ruban, V. V., Ursalov, V. N. 1986. Istoriia denezhnogo obrashcheniia na selskoi territorii Borisfenidy i Olvii dogetskogo vremeni. Vestnik drevnei istorii, 4, s. 31-53.

Rostovtsev, M. I. 1907. Mitridat Pontiiskii i Olviia. Izvestiia arkheologicheskoi komissii, 23, s. 21-27.

Sekerskaia, N. M., Bulatovich, S. A. Monetnye nakhodki iz Nikoniia (1964-2010 gg.). In: Bruiako, I. V. (ed.). Zapysky viddilu numizmatyky $i$ torevtyky Odeskoho arkheolohichnoho muzeiu. Odesa: SMYL, s. 27-38.

Snytko, I. A., Turovskii, E. Ia. 2000. O monetakh Olvii Khersonesa s izobrazheniiami strelkov iz luka. Khersonesski sbornik, 10, s. 399-404.

Frolova, N. A., Abramzon, M. G. 2005. Monety Olvii v sobranii Gosudarstvennogo istoricheskogo muzeia. Katalog. Moskva: RossPEn.

Kharko, V. P. 1964. Monety iz raskopok Olvii v 19461947 gg. In: Gaidukevich, V. F. (ed.). Olviia. Temenos $i$ agora. Moskva; Leningrad: Nauka, s. 321-379.

Braund, D. 2007. Black Sea Grain for Athens? From Herodotus to Demosthenes. Black Sea Studies, 6, p. 39-68.

Bujskich, S. B. 2006. Die Chora des Pontischen Olbia: Die Hauptetappen der räumlich-strukturellen Entwicklung. Black Sea Studies, 4, S. 115-139.

Chistov, D. 2019. The Chronology of Arrowhead and Dolphin-Shaped Monetary Signs from Berezan. In: Tsetskhladze G. R. Atasoy, S. (eds.). Settlements and Necropolis of the Black Sea and its Hinterland in Antiquity. Select Papers from the Third International Conference "The Black Sea in Antiquity and Tekkeköy: An Ancient Settlement on the Southern Black Sea Coast", 27-29 October 2017. Tekkeköy: Archaeopress Archaeology, p. 99-107.

Fornasier, J. 2016. Die griechische Kolonisation im nördlichen Schwarzmeerraum vom 7. bis 5. Jahrhundert v. Chr. Archäologie in Eurasien, 32. Bonn: Habelt.

Fornasier, J. Bujskich, A. V., Kuz'miščev, A. G., Patzelt, A., Helfert, M., Kratzsch, N. 2017. Vor den Toren der Stadt. Deutsch-ukrainische Forschungen in der Vorstadt von Olbia Pontike. Archäologischer Anzeiger, 1, S. 19-61.
Moreno, A. 2007. Athenian Wheat-Tsars: Black Sea Grain and Elite Culture. Black Sea Studies, 6, p. 69-84.

Reuter, A. 2021. Die Münzen der deutsch-ukrainischen Grabungen 2015-2019 - ein Überblick. In: Fornasier, J. (ed.). An den Ufern des Bug - Internationale Fachtagung anlässlich des Jubiläums: 5 Jahre deutsch-ukrainische Ausgrabungen in Olbia Pontike Goethe Universität Frankfurt am Main. Frankfurt am Main, Germany, 7-9 Oktober 2019, in print.

Stingl, T. 2005. Frühe bronzene Geldformen im Nordwestlichen Schwarzmeerraum. Internationale Archäologie, 6, S. 119-123.

Stolba, V. F. 2008. Fish and Money: Numismatic Evidence for Black Sea Fishing. Black Sea Studies, 2, p. 115-132.

Stolba, V. F. 2015. "Archers» of the Blessed City: City's Deliverance in the Coinage of Early Hellenistic Olbia. Notae Numismaticae, X, p. 43-58.

Talmatchi, G. 2013. New Possible Approach on the Significance of Arrowhead-Shaped Monetary Signs Especially Cast for Trade Purposes. Peuce, IX, p. 307-326.

Wroth, W. 1889. A Catalogue of Greek Coins. Pontus, Paphlagonia, Bithynia, and the Kingdom of Bosporus. London: Longmans \& Co.

\section{R. O. Kozlenko, I. M. Sheiko, A. Reuter}

\section{COINS FROM THE EXCAVATIONS AT THE «T-4» SITE IN OLBIA}

Coins from the excavations of the «T-4» site in 2018 - 2020, located in the Terrace City of Olbia, are introduced into scientific circulation. The total number of coins found during three years of research is 154 items, half of which are dolphin-shaped coins. These include a treasure of coins and bronze items, which, in particular, contained 26 casted dolphin-shaped coins. The coin in the shape of a "wheel» from the West Pontic city of Istria also belongs to the Classical period. Coins of the Hellenistic era from the excavations at the «T-4» sector are represented by denominations with images of Apollo, Demeter and the eagle on a dolphin, Tyche in a crown in the shape of a tower and an archer, and borysthenes coins. Among the numismatic monuments of this time is a rare coin of the city of byzantium of the IV c. BC, which confirms the evidence of the Olbian inscription (HO 9) on trade contacts between these cities during the Hellenistic period.

The latest coins of the pre-Getae Olbia are represented by coins of the Asia Minor city of Amis, which are dated by the end of the II - the first half of the I c. BC. These are tetrachalkos with images of the Ares head in a helmet and a sword in sheath, and Aegis with the head of Medusa and Nike. Their appearance in Olbia is associated with the inclusion of the city in the Pontic state of Mithradates VI Eupator, in particular the localization of the Pontic garrison in Olbia.

Coins of Roman times are represented by Olbian assarius such as Zeus / eagle of the middle of the I c. $\mathrm{AD}$, dupondius of the second half of the II c, $\mathrm{AD}$ and a tressis depicting the Roman Empress Julia Mamaeia, which belongs to the last series of monetary units of the Olbian autonomous minting. In general, the available numismatic material from the excavations of the T-4 site is dated from the second half of the VI c. BC, and until the cessation of coinage in the second third of the III c. AD, i. e. covers all major chronological periods of existence of Olbian polis.

Keywords: Olbia, «T-4» site, dolphin-shaped coins, borysthenes coins, Byzantium, Amis, Istria. 


\section{Р. О. Козленко, I. М. Шейко, А. Ройтер}

\section{МОНЕТИ 3 РОЗКОПОК ДІЛЯНКИ «Т-4» В ОЛЬВІї}

До наукового обігу вводяться монети з розкопок ділянки «Т-4», закладеної в Терасній частині Ольвї в 2018 р. Загальна кількість знайдених монет за три роки досліджень становить 154 одиниці, половину з яких складають монети-дельфіни. До них належить і скарб монет та бронзових виробів, у якому, зокрема, містилося 26 литих фігурних монет-дельфінів. До класичного часу також належить монета у вигляді колеса з Західно-Понтійського міста Істрія. Монети елліністичного часу з розкопок ділянки «Т-4» представлені номіналами з зображеннями Аполлона, Деметри та орла на дельфіні, Тюхе в короні у вигляді башти і лучником, та монетами-борисфенами. Серед нумізматичних пам'яток цього часу вирізняеться рідка монета міста Візантія IV ст. до н. е., яка підтверджуе свідчення ольвійського напису (HО 9) про торгівельні контакти між цими містами в елліністичний період.

Найбільш пізні екземпляри монет догетської Ольвії представлені монетами малоазійського міста Аміс, які датуються кін. II - першою половиною I ст. до н. е. Це - тетрахалки з зображеннями голови Ареса в шоломі та меча в піхвах, та Егіди з головою Горгони та Ніки. Їх поява в Ольвії пов’язана 3 включенням міста до складу Понтійської держави Мітрідата VI Свпатора, зокрема розміщенням в Ольвії понтійської залоги.

Монети римського часу представлені ольвійськими ассаріями типу Зевс/орел середини I ст. н. е., дупондіями другої половини II ст. н. е., та трессіом iз зображенням римської імператриці Юлії Мамеї, який належить до останньої серії грошових одиниць ольвійського автономного карбування. Загалом, наявний нумізматичний матеріал з розкопок ділян- ки «T-4» датуеться від другої половини VI ст. до н. е., і до припинення монетного карбування в другій третині III ст. н. е., тобто охоплюе всі основні хронологічні періоди існування Ольвійського полісу.

Ключові слова: Ольвія, ділянка «Т-4», монетидельфіни, монети-борисфени, Візантій, Аміс, Істрія.

Одержано 15.12.2020

КОЗЛЕНКО Роман Олександрович, кандидат історичних наук, молодший науковий співробітник, Національний історико-археологічний заповідник «Ольвія» НАН України, с. Парутине, Україна.

KOZLENKO Roman, Ph D, Junior Research Fellow, National Historical-Archaeological reserve "Olbia", National Academy of Sciences of Ukraine, Parutyne village, Ukraine.

ORCID: 0000-0001-5602-7796, e-mail:

rknovel@ukr.net.

РОЙТЕР Аксель, науковий асистент, Франкфуртський університет I. В. Гете, Франкоурт-на-Майні, Німеччина.

REUTER Axel, M. A., Scientific Assistant, GoetheUniversity Frankfurt am Main, Frankfurt am Main, Germany.

ORCID: 0000-0003-4224-7151, e-mail: ax.reuter@em.uni-frankfurt.de.

ШЕЙКО Ірина Миколаївна, кандидат історичних наук, науковий співробітник, Інститут археології НАН України, Київ, Україна.

SHEIKO Iryna, Ph D, Research Fellow, Institute of Archaeology, National Academy of Sciences of Ukraine, Kyiv, Ukraine.

ORCID: 0000-0003-2005-3081, e-mail:

ira.sheiko@gmail.com.

НО - Надписи Ольвии

IOSPE - Inscriptiones antiquae orae septentrionalis Ponti Euxini Graecae et Latinae

SNG - Sylloge Nummorum Graecorum 